\title{
Yehuda Halevi'nin el-Kitâbï'l-Hazerîde (Kuzari) Ortaya Koyduğu Yahudilik Savunusu ve İslâm’a Yönelik Eleştirileri
}

\author{
Salime Leyla Gürkan*
}

\begin{abstract}
Ortaçağ Yahudi düşüncesinde akılcı çizgiye karşı gelenekçi çizginin en önemli savunucularından olan Endülüslü Yahudi şair ve düşünür Yehuda Halevi (ö. 1141), Siyon üzerine yazdığı dinî-milliyetçi mahiyetteki şiirlerinin yanı sıra el-Kitâbül-Hazerî ya da Sefer haKuzari adlı polemik kitabıyla, hem kendi döneminde hem de sonraki dönemlerde Yahudiler üzerinde etkili olmuş bir şahsiyettir. Halevi, Türk akademyasında fazla tanınmasa da, gerek şiirleri gerekse Kuzari'de ortaya koyduğu görüşleri üzerine Batı'da önemli çalışmalar yapılmıştır. Bu makale, konu üzerine oluşturulmuş zengin ikincil literatürü dikkate alacak şekilde, Halevi'yi ve Kuzari'sini tanıtmayı ve Kuzaride ortaya konan Yahudilik savunusu ve İslâm eleştirisini temel noktalar üzerinden değerlendirmeyi amaçlamaktadır.
\end{abstract}

Anahtar kelimeler: Yehuda Halevi, el-Kitâbü’l-Hazerî, Kuzari, Yahudilik, İslâm, İsrâiloğulları, Yahudiler, seçilmişlik, reddiye.

Ortaçağ’ın en büyük Yahudi din âlimi ve filozofu kabul edilen Mûsâ b. Meymûn (Maimonides), Türk akademyasında oldukça iyi bilinen bir isimdir. Özellikle meşhur felsefe eseri Delâletü'l-hâirîn'de (1200) ortaya koyduğu görüşleri üzerine Türkçe'de de müstakil çalışmalar yapılmıştır. İbn Meymûn’un temsil ettiği akılcı çizgiye karşı gelenekçi çizginin en önemli savunucularından olan ünlü Yahudi şair ve düşünür Yehuda b. Samuel Halevi/Ha-Levi ${ }^{1}$ (Ebü'l-Hasan el-Lâvî) ise Ortaçağ Yahudi düşüncesinin bir diğer önemli ve etkili eserinin, meşhur adıyla el-Kitâbü'l-Hazerî ya da İbrânîce adıyla Sefer

* Prof. Dr., İstanbul 29 Mayıs Üniversitesi Uluslararası İslam ve Din Bilimleri Fakültesi (ORCID oooo-0003-1975-1894 slgurkan@29mayis.edu.tr). Bu makalede kullanılan kaynaklardan bir kısmının temini konusundaki yardımlarından dolayı Neslihan Kuran’a teşekkürü bir borç bilirim.

1 İsmin doğru imlası Ha-Levi şeklinde olmakla birlikte Halevi yazımı yaygın olarak kullanıldığından, makale boyunca bu imla tercih edilmiştir. 
ha-Kuzari’nin ${ }^{2}$ (1140) yazarı olmasına rağmen, Türk akademyasında yeteri kadar tanınmamaktadır. Halevi, Yahudiliği benimseyen tarihî Türk Hazar Krallığı örneğinden hareketle ${ }^{3}$ Hazar kralı ile bir Yahudi din âlimi (haham) arasında geçen diyalog tarzında kurguladığı Kuzarisinde, ${ }^{4}$ Yahudiliğin hakikatini ve diğer inançlara üstünlügünü ortaya koymaya çalışmaktadır. Bunu yaparken özellikle Rabbânî Yahudiliğe muhalif gördüğü grupların, yani filozofların, Karâiler'in, Müslümanlar’ın ve Hıristiyanlar’n temel inançlarını ve görüşlerini doğrudan veya dolaylı yoldan eleştirmektedir. Kuzari'de ortaya

2 Kitabın tam Arapça yazmasında yer alan başlı̆̆ 1 er-Red ve'd-delîl fidd-dîni'z-zelîl'dir. Bir Geniza fragmanındaki başlı̆̆ı ise el-Hücce ve'd-delîl fî̀ nusri'd-dînizz-zelîl şeklindedir. Kitabın ilk İbrânîce tercümesini yapan Yehuda İbn Tibbon, kitabı -baş karakteri olan Hazar kralına atıfla- Sefer ha-Kuzari (1167) şeklinde adlandırmış ve eser Yahudi dünyasında bu tercüme ve bu adla tanınmıştır. Kahire Genizası'nda bulunan bir mektubunda bizzat Halevi'nin de, yakın dostu Ebû Saîd Halfon b. Netanel'e, heretik inanca sahip bir Yahudinin iddialarına cevap olarak bir metin yazdığından bahsettiği ve bu metne elKitâbüll-Hazerî şeklinde atıf yaptığı bilinmektedir (bk. Lasker, “Translations of Rabbi Judah Halevi's Kuzari", dn. 2; Lobel, Between Mysticism and Philosophy, s. 182, dn. 4; Goitein, "Autographs of Yehuda Hallevi”, s. 402). Söz konusu metin, er-Red ve'd-delîl' in ilk biçimi kabul edilmektedir. Tercüme ve edisyonları için bk. Silman, Philosopher and Prophet, s. 345-46; Oğuz, Yehuda Halevi ve Kitabu'l-Huzari'si, s. 32-35.

3 Tarihî Türk Hazar Krallığı’nın -yönetici kesiminin- Yahudiliği benimsediğine yönelik bilgi ilk olarak Ortaçağ İslâm tarihçilerinin eserlerinde yer almıştır. Mes'ûdî (X. yüzyıl) Mürûcü'z-zeheb’inde (I, 178), Halife Hârûnürreşîd döneminde (IX. yüzyıl) Hazar kralının Yahudi olduğundan bahsetmektedir. Ayrıca X. yüzyılda yaşamış Endülüslü Yahudi devlet adamı Hasday (veya Hisday) İbn Şaprut ile dönemin Hazar Kralı Yosef arasında geçen İbrânîce yazışma da buna işaret etmektedir. İbn Şaprut Hazar kralına yazdığı mektupta Hazar ülkesi ve halkı hakkında sorular sormakta ve İspanya hakkında bilgi vermektedir. Hazar kralı ise cevap olarak ilk Hazar krallarından olan Bulan’n, gördüğü bir rüya üzerine, Hıristiyan, Müslüman ve Yahudi din âlimlerine sarayında yaptırdığg münazaranın ardından Yahudiliği benimseme hikâyesini anlatmakta, ayrıca Hazar Krallığı ve krallığın başşehri hakkında bilgi vermektedir. Fakat söz konusu mektupların otantikliği konusunda erken dönemlerden itibaren ciddi şüpheler ortaya konmuştur. Halevi’nin, Kuzarìnin başında, "tarih kitaplarında anlatıldığına göre dört asır önce [takriben 740 yılında] Yahudi dinine giren Hazar kralının huzurunda bulunmuş bir hahamın iddiaları hakkında duyduklarım" ifadesini kullanması, bu kaynakların bir kısmından haberdar olduğunu göstermektedir. Halevi’nin, bahsi geçen İbrânîce yazışmada yer aldığı üzere, dönemin Hazar Kralı Bulan’’n davetiyle sarayda farklı inanç mensupları arasında geçen münazara modelini bazı değişikliklerle kendi kitabına uyarladığı anlaşılmaktadır. Hazar Krallığı’nın Yahudiliği benimsemesi ve ilgili kaynaklara yönelik değerlendirme için bk. Brook, The Jews of Khazaria, s. 77-108; Türkçe'si için bk. Hazar Yahudileri, s. 195-49; Dunlop, The History of the Jewish Khazars, s. 89-170; Stampfer, “Did the Khazars Convert to Judaism?", s. 1-72; Kuzgun, Hazar ve Karay Türkleri, s. 96-112; Taşağıl, "Hazarlar", s. 119. Stampfer, makalesinde, böyle bir din değiştirme hadisesinin vuku bulmadığı tezini savunmaktadır

4 Makale boyunca Halevi’nin eserinden, pratik olması sebebiyle, İbrânîce adıyla Kuzari şeklinde bahsedilmektedir. Atıflarda ise eserin Arapça neşri esas alındığından, orijinal adı olan el-Kitâbü'l-Hazerî adı kullanılmaktadır. 
koyduğu görüşlerden hareketle Halevi, "Aristo rasyonalizmi tarafından Yahudiliğe yöneltilen eleștirileri tam olarak değerlendirebilen ve ona felsefî bir dille cevap veren ilk Yahudi ortaçağ filozofu" kabul edilmiştir. ${ }^{5}$ Kuzari’nin bir diğer özelliği ise İslâm’a karşı yazılmış ilk Yahudi polemik kitabı (reddiye) olarak görülmesidir. ${ }^{6}$ Yahudi kökenli Müslüman âlim Semev'el (Samuel) b. Yahyâ el-Mağribînin de İfhâmül-Yehûd (1163/1168) adlı reddiyesini kısmen Halevi'nin Kuzari'sine cevap mahiyetinde yazdığ kabul edilmektedir. $^{7}$

Kuzari ile ilgili bir diğer önemli husus Halevi’nin, Müslüman Arap kültürünün etkin olduğu bir coğrafyada ve dönemde yaşamış olması sebebiyle, kitabını yazarken önemli ölçüde İslâmî terminolojiden yararlanmış olmasıdır. Halevi'nin felsefe, kelâm ve tasavvuf gibi farklı İslâmî disiplinlere ait literatürden, hatta doğrudan Kur'an'dan ve hadislerden istifade ettiğine ve söz konusu literatürden ödünç aldığı kavramları (emir/emrullah, ittisal, safvet, kıyas, ictihat, senet, taklit vb.) kendi sistemi içerisinde dönüştürerek kullandığına çeşitli Yahudi yazarlar tarafından işaret edilmiş ve bu konu ayrıntılı biçimde tartışılmıştır. İbn Sînâ felsefesinin ve Müslüman Yeni Eflâtunculuğu’nun Halevi’nin ilk dönem düşüncesi üzerindeki etkisine ilâveten Gazzâlînin görüşlerinin, bilhassa felsefe eleştirisi ve dinî tecrübe vurgusu noktasında, Halevi'nin sonraki düşüncesine yaptığı etkiye ve yine Kuzari'ye yansıyan tasavvufî ve Şiî terminolojiye yönelik olarak Harry Wolfson, Shlomo Pines, Diana Lobel ve Ehud Krinis'in çalışmalarını özellikle zikretmek gerekir. ${ }^{8}$ Daha öncesinde ise David Kaufmann, Ignaz Goldziher, Julius Guttman, David Baneth ve Israel Efros gibi araştırmacılar Kuzarinin arka planında yatan Müslüman etkisine farklı biçimlerde işaret etmişlerdir. ${ }^{9}$ Halevi’nin

5 Kogan, "Judah Halevî", s. 401. Halevi’ye göre vahiy dinine alternatif bir dünya görüşü ortaya koyan Aristo felsefesi, şahsî bir Tanrı fikrini, peygamberliği, vahyedilmiş Tevrat'ı ve Tevrat kurallarının mutlak manada bağlayıcılığını esas alan Yahudi inancına tehdit oluşturmaktadır. Bk. Schweid, The Classic Jewish Philosophers, s. 98.

6 Hartwig Hirschfeld tarafından işaret edildiği üzere, Hıristiyanlığa karşı yazılmış ilk Yahudi reddiyesinin ise David ha-Bavlî diye de bilinen, IX-X. yüzyıllarda yaşamış Karâî (?) âlim İbn Mervan el-Mukammis’e (veya Mukammas) ait iki ayrı risâle olduğu kabul edilmektedir (Işrûn makālât ve er-Red ale’n-nasârâ min tarîkı'l-kıyâs). Bk. "Introduction", s. 30-31.

7 Bk. Hirschfeld, “Introduction", s. 31.

8 Kuzari'de yer alan sûfî kavramlar üzerine yapılmış iki önemli çalışma S. Pines’ın, "Shi'ite Terms and Conceptions in Halevi's Kuzari" başlıklı makalesi ile D. Lobel'in Between Mysticism and Philosophy başlıklı kitabıdır. Kuzari'de yer alan Yahudi mistik geleneğine (Kabala) ait kavramlar için ayrıca bk. Wolfson, "Merkavah Traditions in Philosophical Garb: Judah Halevi Reconsidered”, s. 179-242.

9 Bütün bu bilgiler için bk. Lobel, Between Mysticism and Philosophy, s. 6-9; ayrıca bk. Krinis, "The Arabic Background of the Kuzari", s. 1-56; Baneth, "Judah Halevi and alGhazali", s. 181-99. 
Kuzaride İslâm eleştirisi yapmasına rağmen ciddi biçimde Müslüman geleneğinden beslenmesi ise meselenin ironik tarafını oluşturmaktadır. Kuzari'yi İngilizce'ye çeviren Hartwig Hirschfeld, Halevi’nin bir yandan İslâm’ı tenkit ederken diğer yandan Gazzâlînin etkisine kapıldığını söyleyerek söz konusu ironiye işaret etmiştir. ${ }^{10}$

$\mathrm{Bu}$ makale, Halevi’nin Kuzari’si üzerine oluşturulmuş zengin içerikli ikincil literatürü de dikkate alacak şekilde, Halevi'nin Kuzari'deki Yahudilik savunusunu ve buna paralel olarak ortaya koyduğu İslâm eleştirisini konu edinmektedir. Öncelikle Halevi'nin hayatına dair genel bilgi verildikten sonra Kuzarinin kurgusu ve yazılma amacı hakkında yapılan yorumlar değerlendirilecek, sonrasında ise Halevi'nin hangi temel noktalar üzerinden Yahudiliğin üstünlügünü savunduğu ve İslâm’a eleştiri yönelttiği, birbiriyle bağlantılı biçimde ele alınacaktır. Bu noktada vurgulanması gereken bir husus Halevi’nin söz konusu savunusunun ve eleştirisinin Kur'an’ın Yahudilere yönelik tenkitlerine de kısmî ve dolaylı bir cevap niteliği taşıdığıdır.

\section{Halevi'nin Yetiştiği Ortam ve Hayatına Dair Bilinenler}

İbn Meymûn gibi bir Endülüs Yahudisi olan Halevi, Endülüs için siyasî aç1dan çalkantılı bir asır olan XI. yüzyılın son çeyreğinde yani İbn Meymûn'dan yarım asır kadar önce, eğitimli ve varlıklı bir ailenin çocuğu olarak dünyaya gelmiştir. Halevi'nin doğum tarihi konusunda genellikle 1080 ve 1085 yılları veya daha erken bir tarih olarak 1075 ve hatta 1070 yllları zikredilmektedir. ${ }^{11}$ Doğduğu yerle ilgili yaygın görüş Endülüs'ün merkezinde yer alan Tuleytula (Toledo) şeklinde olsa da, Endülüs'ün kuzey sınırındaki Tutîle (Tudela) daha isabetli görülmektedir. ${ }^{12}$ Kesin olan husus, Halevi’nin, Yahudiler'in çoğunluğunun Müslüman coğrafyada yaşadığı bir dönemde ve Batı diyasporasına denk gelen İspanya'da doğup büyümüş olduğudur. Fakat yetiştiği asır, İspanyada 711 yılından beri devam eden Müslüman Arap hâkimiyetinin, yerini Hıristiyan hâkimiyetine bırakmaya başladığı bir zamana yani "reconquista” (Endülüs'ü Müslümanlar'dan geri alma ve yeniden Hıristiyanlaştırma) hareketinin fiilî olarak başlangıcına denk gelmektedir. ${ }^{13}$ Bununla birlikte

10 Hirschfeld, "Introduction", s. 6.

11 Bk. Scheindlin, The Song of the Distant Dove, s. 12, 254 (dn. 3); Lobel, Between Mysticism and Philosophy, s. 1; Halkin, Yehuda Halevi, s. 3; Goitein, "The Biography of Rabbi Judah Ha-Levi", s. 42; Baron, "Yehudah Halevi", s. 244.

12 Bk. Guttman, Philosophies of Judaism, s. 136; Cohon, "Jehuda Halevi”, s. 450; Lasker, "Judah Halevi", s. 493.

13711 yılında Târık b. Ziyâd kumandasındaki Emevî ordusu tarafından fethedilen Endülüs'te (Güney İspanya) “valiler dönemi”nin ardından 755 yılında kurulan bağımsız 
Müslüman Arap dili ve kültürü, aynı zamanda Müslüman siyasî nüfuzu, XI. yüzyılın sonunda Endülüs'e hâkim olan Kuzey Afrika kökenli Murâbıtlar ve daha sonra Muvahhidler yoluyla, bölgedeki etkisini sürdürmüştür. Halevi, ana dili durumundaki Arapça'nın yanı sıra İbrânîce ve Kastilce (Ortaçağ İspanyolcası) öğrenmiş, Tanah ve Talmud, Arap şiiri ve İbrânîce grameri, Grek felsefesi ve tıp konularında eğitim almıştır. ${ }^{14}$ İbn Meymûn gibi geçimini hekimlikten kazanan ve saray hekimliği de yapan, ayrıca Mısır'daki Yahudi dostları aracılığıyla ticaretle de uğraştığı bilinen Halevi, İspanyảnın farklı şehirlerinde bulunmuştur. Bir süre, Hıristiyan hâkimiyetindeki Kastilya bölgesinde (Kuzey İspanya) yaşayan Halevi "Kastilyalı" lakabıyla da anılmıştır. Hıristiyan kontrolündeki Toledo'nun yanı sıra Müslüman yönetimindeki Kurtuba (Kordoba), Lusina ve Gırnata (Granada) şehirlerinde yaşadığ mektedir. ${ }^{15}$ Şiirlerinde Kuzey İspanya'dan, Tevrat'ta geçen ve gelenek içinde pejoratif anlamda Hiristiyanlar'la ilişkilendirilen bölge isimlerinden hareketle "Seir" ve "Edom” şeklinde, Güney ya da Müslüman İspanya'dan yani Endülüs'ten ise Tanah’ta geçen ve gelenek tarafından İspanya bölgesi için kullanılan, nötr çağrışıma sahip "Sefarad” adıyla bahsetmiştir. ${ }^{16}$ Fakat gerek

Endülüs Emevî Devleti 1030 yılına kadar varlı̆̆ını sürdürmüş, Kurtuba’nın (Kordoba) bir din ve ilim merkezi haline geldiği bu dönem Yahudiler' in "altın çağg" (tor ha-zahav / el-'asrü̉z-zehebî) şeklinde nitelendirilmiştir. Endülüs Emevî Devleti’nin ardından ortaya çıkan ve "tayfa yönetimler" diye adlandırılan Arap ve Berberî emirlikleri döneminde Kurtuba eski önemini kaybetmeye başlasa da Gırnata (Granada), İşbîliye (Sevilla), Lusina, Sarakusta (Zaragosa), Tuleytula (Toledo) ve Tutîle (Tudela) gibi şehirler Yahudi cemaatler için din ve ilim merkezi olmaya devam etmiştir. Halevi’nin doğduğu veya yetiştiği tarih kabul edilen 1085'te ise Endülüs'ün ikinci büyük şehri olan Tuleytula, reconquista hareketi doğrultusunda Kastilya Kralı VI. Alfonso tarafından ele geçirilmiştir. İşbîliye yönetiminin Kuzey Afrika'da hüküm süren Murâbıtlar'dan yardım istemesi üzerine bölgeye yardım gönderen Murâbıtlar, bir süre sonra Endülüs'ün yönetimini ele geçirmiştir (1090). Bu dönemden itibaren eski rahat konumlarını kaybetmeye başlayan Endülüs Yahudileri XII. yüzyılın ikinci yarısında bölgenin yine Kuzey Afrika kökenli bir grup olan Muvahhidler'in yönetimine girmesinin ardından (1146/1147) din değiştirme baskısıyla da karşı karşıya kalmışlardır. XIII. yüzyılda ise güneydeki Gırnata bölgesi hariç Endülüs'ün büyük bölümü Hıristiyan Kastilya yönetimi tarafından ele geçirilmiştir. Bütün bu dönem boyunca, Halevi gibi, daha az baskı gördükleri yerlere göç eden kimi Yahudiler, Müslüman Endülüs ile Hıristiyan yönetimindeki Kuzey İspanya arasında gidip gelmişlerdir. Yahudiler'in Ortaçağ İspanyası'ndaki konumuyla ilgili bilgi için bk. Scheindlin, "The Jews in Muslim Spain”, s. 188-200; Hellig, "The Jewish Golden Age of Spain Revisited”, s. 23-33; ayrica bk. Menocal, The Ornament of the World; Baer, A History of the Jews in Christian Spain, I.

14 Cohon, "Jehuda Halevi", s. 451.

15 Cohon, "Jehuda Halevi", s. 451-55.

16 Kfir, A New Perspective on Medieval Hebrew Poetry, s. 52, 6o; Cohon, "Jehuda Halevi", s. 451. Tevrat'taki ilgili ifadeler için bk. Tekvin 36:21; Sayılar 24:18; Tesniye 33:2; Obadya 1:20. 
her iki bölge gerekse, sırasıyla Arap/İsmâilî ve Edom diye isimlendirdiği Müslümanlar ve Hıristiyanlar hakkında şiirlerinde genellikle olumsuz ifadeler kullanmıştır. ${ }^{17}$ Halevi’nin kendisini İspanya'da sürgünde olarak tanımladığı ve Filistin'e olan özlemini dile getirdiği en meşhur dizelerinden biri, "Kalbim doğuda, bense batının en uzağındayım..." şeklindedir.

Endülüslü çağdaşları arasında, Lusina'daki Yahudi din akademisine (yeşiva) başkanlık eden ve Yahudi hukukunun ilk derleyicilerinden olan Yitshak Alfasi, Alfasi’nin halefi Yosef İbn Migaş, Yahudi müfessiri Abraham İbn Ezra, şair Moşe İbn Ezra ve kardeşi Yitshak İbn Ezra, kendisi gibi Kastilya Kralı VI. Alfonso’nun hekimliğini yapmış olan Yahudi kökenli Hıristiyan polemikçi Petrus Alfonsi (eski adıyla Moșe Sefardi) yer almaktadır. Alfasi'den ders alıp almadığı tartışmalıdır; fakat her üç İbn Ezra ile yakın dostluk kurduğu bilinmektedir. ${ }^{18}$

Kahire Genizası'nda bulunan yazışmalardan ve kendi şiirlerinden edinilen bilgilere göre, ${ }^{19}$ Kuzari yi tamamladıktan ${ }^{20}$ kısa bir süre sonra Filistin'e gitmek üzere yola çıkan ve 8 Eylül 1140 tarihinde Memlük hâkimiyetindeki Mısır’a ulaşan Halevi, İskenderiye ve Kahire şehirlerinde geçirdiği sekiz aylık sürenin ardından, buradaki dostlarının Mısır'da kalması yönündeki ısrarlarına rağmen zorlu Filistin yolculuğuna devam etmeyi tercih etmiş ve 14 Mayıs 1141'de İskenderiye limanından Filistin’e (Akra veya Aşkelon/ Askalân Limanı) hareket eden gemiye binmiştir. Bilinen en son şiirini de bu gemide yazan Halevi, dostlarına ait mektuplardan anlaşıldığı kadarıyla 1141 yazında muhtemelen Temmuz ayında vefat etmiştir. ${ }^{21}$ Filistin’e varıp

17 Bk. Rosenzweig, Ninety-Two Poems and Hymns of Yehuda Halevi, s. 204, 210, 234, 246; ayrica bk. Cohon, "Jehuda Halevi", s. 458-64; Dover, "The Racial Philosophy of Jehuda Halevi", s. 313-14.

18 Cohon, "Jehuda Halevi”, s. 451; Lasker, “Judah Halevi”, s. 493. Goitein, “The Biography of Rabbi Judah Ha-Levi”, 43; ayrıca bk. Malkiel, “Three Perspectives on Judah Halevi’s Voyage to Palestine", s. 2-4.

19 Halevi’nin hayatıyla ilgili olarak Geniza yazışmalarından hareketle Goitein’n ve Baneth'in Tarbiz dergisinde İbrânîce basılan çalışmaları için bk Goitein, "Autographs of Yehuda Hallevi", s. 393-412; Baneth, "Some Remarks on the Autographs of Yehudah Hallevi", s. 297-303. Goitein’n İngilizce makalesi için ayrıca bk. "The Biography of Rabbi Judah Ha-Levi”, s. 41-56 (aynı yazı Goitein'n kendi telifi olan A Mediterranean Society, V, 448-68'de de yayımlanmıştır).

20 Kuzari’nin İngilizce tercümesinde (1:46-47) Hazar kralının sorusu üzerine haham, içinde bulundukları yıl için Yahudi takvimine göre 4900 rakamını zikretmektedir (bk. Hirschfeld, "Introduction", s. 6; Cohon, "Jehuda Halevi”, s. 466). Bu tarih milâdî takvime göre 1140 yılına tekabül etmektedir. Fakat kitabın Arapça neşirlerinde söz konusu tarih 4500 şeklinde geçmektedir (bk. Lâvî, el-Kitâbüll-Hazerî, s. 181; Halevi, Sefer Ha-Kuzari, s. 14).

21 Bk. Goitein, “The Biography of Rabbi Judah Ha-Levi”, s. 51-52, 55-56; Scheindlin, The Song of the Distant Dove, s. 152. Kahire Genizası'nda bulunan, Halevi'nin yakın dostu 
varmadığ 1 konusunda kesin bilgi mevcut olmasa da gemiye bindikten en geç iki ay sonra ölmüş olduğu düşünüldüğünde, Filistin'e varmış olması kuvvetle muhtemel görülmektedir. ${ }^{22}$ Bununla birlikte Halevi’nin Kudüs’te, şehrin kapılarına ulaştı̆̆ı sırada sergilediği dinî coşkudan rahatsız olan fanatik bir Müslüman atlı tarafından ezilerek öldürüldüğüne yönelik rivayetin bir menkıbeden ibaret olduğu anlaşılmaktadır. Raymond Scheindlin ve diğer araştırmacılar tarafından dikkat çekildiği üzere, o dönem Haçlılar’’n hâkimiyetinde olan Kudüs'te bir Müslüman’ın, bırakın atlı, yaya olarak dahi açık Müslüman kimliğiyle yaşaması mümkün değildi. ${ }^{23}$ Ayrıca Halevi'den iki asır sonra yaşamış bir İtalyan Yahudisi olan Gedalya İbn Yahyâ tarafından aktarılan bu rivayetin hiçbir otantik kaynağa dayanmadığına ve Halevi’nin tanıdıklarına ait mektuplarda da böyle bir olaydan bahsedilmediğine dikkat çeken Scheindlin, söz konusu menkıbenin Halevi’yi şehit konumuna yükseltmek adına kurgulanmış olabileceğini ileri sürmüş, bizzat Halevi’nin şiirlerinde ve Kuzari'de ortaya koyduğu Siyon sevgisi ve kutsal topraklara kavuşarak ya da karışarak canını verme arzusunun $\mathrm{da}^{24}$ bunda etkili olmuş olabileceğini belirtmiştir. ${ }^{25}$ Öte yandan Halevi’nin hayattayken de "dindar" (tsadik) ve

Ebû Saîd Halfon b. Netanel’e yazılmış bir mektupta beş ay içinde ölen üç büyük şahsiyetten bahsedilmektedir. Buradan hareketle Goitein, bunlardan adı belirtilmeyen sonuncusunun Halevi olduğu ve 8 Haziran - 5 Ağustos arasındaki bir tarihte öldügü sonucuna varmıştır (bk. Scheindlin, The Song of the Distant Dove, s. 152, 276, dn. 22; Goitein, "The Biography of Rabbi Judah Ha-Levi”, s. 45-46). Öte yandan Ortaçağ Yahudi seyyahı Tudelalı Binyamin'in seyahatnâmesinde Filistin'in Taberiye şehrinde medfun iki hahamdan bahsedilmektedir. Bu hahamlardan birinin, seyahatnâmenin bazı nüshalarında Yonatan ben Levi, diğer bazısında ise Yehuda ha-Levi şeklinde geçtiği bilgisi verilmektedir (bk. Tudela’lı Benjamin - Ratisbon'lu Petachia, Ortaçağda İki Yahudi Seyyah, s. 59, dn. 119). Halevi'nin İngilizce biyografilerinde, tespit edebildiğimiz kadarıyla, böyle bir bilgiden bahsedilmemektedir. Seyahatnâmenin İngilizce tercümesinde yer alan isim de Yonatan ben Levi şeklindedir (bk. Asher, The Itenerary of Benjamin of Tudela, s. 81).

22 Bk. Yahalom, “Judah Halevi”, s. 132; Goitein, “The Biography of Rabbi Judah Ha-Levi”, s. 55-56.

23 Scheindlin, The Song of the Distant Dove, s. 249. Ayrica bk. Cohon, "Jehuda Halevi", s. 470, dn. 8o. Samuel David Luzatto, söz konusu rivayetin vâkıaya ters düşmesinden hareketle Halevi’nin Filistin’e varamadığı görüşündedir. Ayrıca bu rivayetle ilgili olarak, başlangıçta söz konusu atlıdan Hıristiyan bir süvari şeklinde bahsedildiği, daha sonra bunun Müslüman bir süvari biçimine dönüştüğüne de dikkat çekilmiştir. Bk. Yahalom, "Judah Halevi”, s. 131, 134 vd.

24 Bk. Yahalom, "Judah Halevi”, s. 130; ayrıca bk. el-Kitâbü'l-Hazerî, 5:27. Halevi burada bir Mezmur pasajına atıf yapmaktadır: "Kulların onun taşlarından hoşlanırlar; tozunu bile severler" (102:14).

25 Scheindlin, The Song of the Distant Dove, s. 134; ayrıca bk. Yahalom, "Judah Halevi", s. 134-35. Bu rivayeti bir Yahudi büyügünden duyduğunu söyleyen Gedalya’nın kaynağı belli değildir. 
hatta "aziz" (kadoş) şeklinde nitelendirildiğine işaret eden Scheindlin’e göre bu menkıbe, tarihî gerçekliğe sahip olmasa da, Halevỉnin sadece çağdaşları tarafından değil, sonraki Yahudiler tarafından da bir aziz şeklinde görüldügünün önemli bir göstergesi olmaktadır. ${ }^{26}$

Halevi, yine bir Endülüslü olan İbn Cebirol'dan (ö. 1057?) sonra en büyük Ortaçağ Yahudi şairi unvanına sahiptir. ${ }^{27}$ Şiirlerini, dönemin diğer Yahudi şairleri gibi, Arapça nazım ölçüsüne göre İbrânîce yazmıştır. İbrânîce o dönemde konuşma dili olmamasına rağmen, şiirlerinde bu dili büyük bir ustalıkla kullanmıştır. ${ }^{28}$ Bilhassa dinî konular ve Kudüs üzerine yazdığ 1 şiirleriyle meşhur olan Halevi "Siyon şairi” diye de nitelenmiştir. Şiirlerinden bir kısmı sonraki dönemlerde sinagoglarda ibadet sırasında okunmuştur. Aynı zamanda Halevi, siyasî açıdan istikrarsız bir dönemde yaşamış olsa da, şiirleri sayesinde dönemin Endülüs Yahudi hayatının en iyi aktarıcılarından biri olarak görülmektedir. Dinî şiirlerinde işlediği temalara, bilhassa İsrâiloğulları̉nın seçilmişliği, sürgün ve Filistin topraklarının kutsallığ k konularına, filozof yönünü ortaya çıkaran Kuzaride de yer vermiştir. Guttman’a göre Halevi herhangi bir felsefe ekolüne ait değildir. Bununla birlikte Halevinnin gençliğinde, dönemin hâkim düşünce akımlarından (Yeni Eflâtunculuk, Aristoculuk ve kelâm) etkilendiğine işaret edilmiştir; daha çok da Yeni Eflâtuncu düşünceyle ilişkilendirilmiştir. ${ }^{29}$ Sonraki çağdaşları tarafından rabbi/haham şeklinde nitelendirilmesine rağmen, Halevỉnin teknik anlamda bir din âlimi olmadığı, hekim ve şair vasıflarının yanı sıra daha çok bir filozof veya kelâmcı şeklinde nitelendirilebileceği ileri sürülmüştür. Ayrıca Geniza'da bulunan yazışmalarda yer alan bilgilerden hareketle Halevi’nin Endülüs'te Yahudi cemaatinin liderliğini de yaptığı sonucuna ulaşılmıştır. ${ }^{30}$

26 Scheindlin, The Song of the Distant Dove, s. 249-52; ayrıca bk. Yahalom, "Judah Halevi", s. 132-33.

27 Guttman, Philosophies of Judaism, s. 136.

28 Cohon, "Jehuda Halevi", s. 470. Halevi’nin şair kişiliği için ayrıca bk. Brann, "Judah Halevi: The Compunctious Poet", s. 123-43.

29 Guttman, Philosophies of Judaism, s. 136; Spero, "Yehudah Halevi and Philosophical Use of Metaphor," s. 11; Silman, Philosopher and Prophet, s. 9-10; Schweid, The Classic Jewish Philosophers, s. 99; Katzew, "Moses Ibn Ezra and Judah Halevi”, s. 179.

30 Bk. Goitein, "The Biography of Rabbi Judah Ha-Levi", s. 48, 49; A Mediterranean Society, V, 457; ayrica bk. Malkiel, "Three Perspectives on Judah Halevi's Voyage to Palestine”, s. 2. Geniza yazışmalarında Halevỉnin, esir düşen bir Yahudi kadın için cemaatten para topladığı bilgisi yer almaktadır. Ayrıca kendisinden "cemaatimizin mümtaz üyesi ve simgesi, sığınağımız ve liderimiz” şeklinde bahsedilmektedir. Mısır’daki Yahudi cemaati tarafından gördüğü itibar da bu hususu desteklemektedir. 


\section{Kuzari'nin İçeriği ve Yazılma Amacı}

Daha çok şair yönüyle bilinen Halevi’nin ${ }^{31}$ felsefe ile alâkalı tek eseri Kuzari'dir. Yaygın biçimde bir polemik kitabı (apoloji) şeklinde görülse de Kuzari yi aynı zamanda felsefe/teoloji ya da daha ziyade "dinî felsefe" kategorisinde değerlendiren araştırmacılar da vardır. ${ }^{32}$ Halevi’nin Kuzari'yi diyalog tarzında yazmış olması, şair ve filozof kimliklerinin kesişimi şeklinde görülmektedir. ${ }^{33}$ Esasen Halevỉnin felsefe ile olan ilişkisi de farklı biçimlerde yorumlanmıştır. Halevỉnin, dinî hakikate ulaşmada felsefeyi tamamen işlevsiz gördüğünü yani akılcılık karşıtı olduğunu ileri sürenlerin yanında (Kauffman, Guttman, Wolfson), aynı Halevi’nin, felsefecilerin dinî düşünceye yaptıkları katkıyı takdir ettiğini söyleyenler de vardır (Neumark). ${ }^{34}$ Dahası, her iki çıkarım için de Kuzari'den dayanak bulmak mümkündür. Yine Kuzarinin temel hedefinin ne olduğu konusunda da görüş farklıllğı mevcuttur: Amaç, Yahudi dinini felsefeye karşı mı savunmak yoksa Yahudi dininin diğer iki monoteist din karşısındaki üstünlügünü mü ortaya koymak? ${ }^{35}$ Bütün bu ç1karım ve yorum farklılıklarının, kısmen, Kuzarinin sistematik ve monolitik bir metin olmamasından kaynaklandığı düşünülebilir. Aşağıda değinileceği üzere, mevcut şekliyle Kuzari, Halevỉnin düşüncesinin farklı dönemlerini yansıtan bir metin özelliği taşımaktadır.

Yahudi Arapçası'yla (Judeo-Arabic, yani İbrânî harfleriyle Arapça) kaleme alınan ve beş bölümden oluşan Kuzarinnin birinci bölümünde, gördüğü bir rüya üzerine hakikat arayışına giren Hazar kralının (isim belirtilmemektedir), sırasıyla Aristocu bir filozof, bir Hıristiyan, bir Müslüman ve en sonunda bir Yahudi din âlimine (haver/haham) danışması ve hahamın yaratılış, İsrâiloğulları̉nın kökeni ve Tanrı̉nın fizikî âlemle bağlantı kurması konularına yönelik açıklamalarından etkilenmesinin ardından Yahudi dinine geçmeye karar vermesi anlatılmaktadır. Kralın bilhassa filozofla yaptığ1 ve Halevi’nin önceki görüşlerini yansıttığı kabul edilen açılış konuşması sonraki tartışmaların temelini oluşturmaktadır. Geri kalan dört bölümde

31 Halevi’ye ait olduğu bilinen 800 şiir mevcuttur. Bk. Lasker, “Judah Halevi”, s. 494.

32 Bk. Hirschfeld, "Introduction", s. 5; Kreisel, “Judah Halevi's Influence on Maimonides", s. 102; Halkin, Yehuda Halevi, s. 2; Epstein, "Judah Halevi as Philosopher", s. 201-202; Kaplan, "Judah Halevi as Philosopher, Poet, and Pilgrim", s. 98.

33 Spero, "Yehudah Halevi and Philosophical Use of Metaphor," s. 10. Halevi'nin, kendinden önce yaşayan İbn Cebirol ve Gazzâlî gibi, kitabını diyalog tarzında kurgulamış olmasının Eflâtun'un Diyaloglar'ından mülhem olduğu kabul edilmektedir. Bk. Cohon, "Jehuda Halevi", s. 474; ayrica bk. Hughes, "The Use of Dialogue in Halevi's Kuzari", s. 470.

34 Bk. Epstein, "Judah Halevi as Philosopher", s. 202.

35 Bk. Epstein, “Judah Halevi as Philosopher”, s. 203. 
ise veziriyle birlikte resmî olarak Yahudiliğe geçen ve çevresinde Yahudiliği yaymaya başlayan kralın Yahudi dinini daha iyi öğrenmek için hahamdan eğitim almak istemesi üzerine yine ikili arasında gerçekleşen soru-cevap yoluyla, ağırlıklı olarak teoloji konuları ele alınmaktadır. Bu konuların başında da Tanrı'nın sıfatları ve antropomorfizm (tecsîm ve teşbih), İsrâiloğulları'nın seçilmişliği ve Filistin topraklarının kutsallığı, dinî emirlerin sebebi, İbrânî dilinin üstünlügü, gelenek ve sözlü Tevrat, peygamberlik, felsefe ve diğer dinler, yaratılış, kader ve hür irade bahisleri gelmektedir. Kitap, hahamın gerekli bütün açıklamaları yaptıktan sonra, söylediklerinde tutarlı olmak adına Filistin topraklarına yani Kudüs'e gitmeye karar vermesiyle son bulmaktadır.

Genellikle ele alınan konularda tam bir sistematiğin takip edilmemesi, kimi zaman aynı konuya tekrar dönüş yapılması ve bölümler arası üslûp, anlatım ve anlayış farklılıklarından dolayı Kuzari'nin mevcut kurgusu ve yazılma amacı konusunda farklı yorumlar ortaya konmuştur. ${ }^{36} \mathrm{Bu}$ yorumların hepsinde, kitabı oluşturan bölümlerin içerik ve üslûbuyla ilgili mülâhazaların yanı sıra Kahire Genizası'nda bulunan, Halevi'ye ait bir mektup çıkış noktasını oluşturmaktadır. Kahireli bir tüccar olan yakın dostu Ebû Saîd Halfon b. Netanel'e hitaben yazdı̆̆g söz konusu mektupta Halevi, Hiristiyan İspanya'da (bilâdür-R̂um) yaşayan, heretik inanca (minut) sahip bir Yahudi'nin sorularına cevap olarak küçük bir metin (sahâfe) yazdığından bahsetmekte, fakat sonradan bu metni benimsemediğini belirtmektedir. ${ }^{37}$ Mektupta geçen "heretik inanca sahip" ifadesini yaygın olarak kullanıldı̆̆ı üzere "Karâ̂̀” şeklinde anlayan Goitein’ın yanı sıra, bu ifadeyi sıradan bir Karâînin ötesinde "Karâî filozof" şeklinde yorumlayan Baneth, ${ }^{38}$ Kuzari’nin ilk biçiminin Karâî iddi-

36 Anlatım farkına örnek olarak Hazar kralının gördüğü rüya bahsini verebiliriz. Aynı rüya birinci ve ikinci bölümlerde farklı şekilde anlatılmaktadır. Birinci bölümün başında Hazar kralına rüyasında bir melek tarafından "niyetinin Allah’nn rızasına uygun, fakat amelinin uygun olmadığı"nın söylendiği ve "kendisine Allah katında makbul ameli talep etmesi”nin emredildiği belirtilmekte; bunun üzerine kralın, sırasıyla bir filozof, bir Hıristiyan, bir Müslüman ve bir Yahudi din âlimine danıştıktan sonra bölümün sonuna doğru (1:98) rüyasının sırrını hahamın açıklamalarında bulduğunu ifade ettiği söylenmektedir. İkinci bölümün başında ise Hazar kralının rüyasını önce vezirine açtığı, daha sonra veziriyle birlikte deniz kıyısındaki dağlara çıktıkları, bir grup Yahudỉnin sebt gününü geçirdikleri bir mağaraya denk geldikleri, onlara kendilerini tanıtıp onların dinine girdikleri, mağarada sünnet oldukları ve Yahudi dini üzere yaşamaya azmetmiş olarak memleketlerine döndükleri ve dinlerini tedrîcî olarak yaymaya başladıkları söylenmekte; kralın, Tevrat’ı ve peygamber kitaplarını çalışıp öğrendikten sonra hahamı kendisine hoca tayin ettiği ve ona Yahudilik'le ilgili sorular sorduğu belirtilmektedir.

37 Bk. Goitein, "The Biography of Rabbi Judah Ha-Levi", s. 46; A Mediterranean Society, V, 465.

38 Bk. Friedman, "Judah Ha-Levi on Writing the Kuzari", s. 162; krş. Lasker, "Judah Halevi and Karaism”, s. 111, dn. 2. Friedman’a göre söz konusu kişi esasen Rabbânî geleneğe mensupken sonradan Karâî inancını benimsemiş bir Yahudi'dir (s. 164). 
alarına karşı oluşturulan bu küçük reddiye olduğu sonucuna varmışlardır. ${ }^{39}$ Buna göre Halevi, büyük ölçüde Kuzarỉnin üçüncü bölümüne karşıllk gelen söz konusu reddiyeyi geliştirerek, diyalog tarzında kurguladığı ve o dönem revaçta olan Yeni Eflâtuncu düşüncenin etkisini taşıan ilk dört bölümü yazmıştır; ${ }^{40}$ aynı dönem özellikle İbn Bâcce (ö. 1139) aracılığıyla Batı İslâm dünyasında yükselişe geçen Aristo felsefesine cevap olarak ve daha ziyade monolog üslûbunda yazdığı beşinci bölümü ise sonradan diğer bölümlere eklemiştir. ${ }^{41}$ Nitekim eserin baş kahramanı olan Hazar kralı ilk dört bölümde hahama Yahudiliği anlamaya yönelik sorular yöneltirken, beşinci bölümde ise Aristo felsefesi ve kelâm konusunda hahamdan kendisini bilgilendirmesini istemekte ve bunun üzerine haham, konuyla ilgili olarak monolog tarzı uzun açıklamalarda bulunmaktadır. ${ }^{42}$ Dolayısıyla hem içerik hem de üslûp bakımından ilk dört bölüm ile beşinci bölüm arasında farklılık bulunmaktadır.

Baneth ve Goitein'ın bu yorumuna karşıllk Eliezer Schweid, Halevi’nin mektubunda bahsi geçen Karâî iddialarına yönelik reddiyenin sadece üçüncü bölümle sınırlı olduğunu belirtmiş, önceki ve sonraki bölümlerin ise bu ilk reddiyenin, Karâiler dışındaki muhalif grupların görüşlerini de içerecek şekilde geliştirilmesiyle oluşturulduğunu ileri sürmüştür. ${ }^{43} \mathrm{Bu}$ görüşe kısmen paralel bir diğer görüş olarak, Halevỉnin düşünce sisteminde bir değişim geçirdiği tespitinde bulunan Yochanan Silman’a göre ise Kuzarinin üçüncü bölümü ile ilk iki bölümünün belli kısımları (1:68-79; 2:1-7) Halevi’nin düşüncesinin Aristo felsefesinin etkisindeki ilk döneminin ürünü olmakta, bu kısımlarda Halevi, Aristo felsefesine ait argümanları kullanarak Yahudiliğin doğruluğunu ispatlamaya çalışmaktadır. Halevỉnin Aristo karşıtllğına evrilmiş olan sonraki düşünce yapısını yansıtan son iki bölüm ile ilk iki bölümün

39 Bk. Silman, Philosopher and Prophet, s. 116-17. Goitein, Halevi'nin bu mektubu, Hıristiyanlar'ın hâkimiyetindeki Toledo'dan yazdığını belirtmektedir (bk. "The Biography of Rabbi Judah Ha-Levi”, s. 48). Toledo'nun, XII. yüzyılda İspanya'da yaşayan Karâiller'in merkezi olduğuna yönelik bilgi bu açıdan önemlidir (bk. Beinart, "Toledo", s. 23).

40 Goitein’ın daha sonra bu görüşten vazgeçtiğine işaret edilmiştir. Bk. Kogan, "Judah Halevî", s. 396.

41 Bk. Silman, Philosopher and Prophet, s. 116-17; Berger, "Toward a New Understanding of Judah Halevi's 'Kuzari”, s. 211-12; ayrıca bk. Goitein, “The Biography of Rabbi Judah Ha-Levi”, s. 46-47. Bu noktayla bağlantılı olarak Lobel, Kuzari 1:1'de yer alan filozofun argümanlarının İbn Bâcce’nin görüşlerini çağrıştırdığına, 4:12'nin ise İbn Sînânın ruh konulu risâlesinin neredeyse birebir kopyası olduğuna dikkat çekmektedir. Bk. Between Mysticism and Philosophy, s. 170.

42 Bk. Berger, “Toward a New Understanding of Judah Halevi's 'Kuzari”, s. 211-12.

43 Schweid, The Classic Jewish Philosophers, s. 96; ayrica bk. Silman, Philosopher and Prophet, s. 117; Berger, "Toward a New Understanding of Judah Halevi's 'Kuzari”', s. 213. 
büyük kısmında ise Aristocu rasyonalist anlayışa karşı, en iyi ifadesini Yahudi geleneğinde bulan dinî tecrübe yani vahiy tecrübesi öne çıkarılmaktadır. ${ }^{44}$ Silman’ın bu yorumu, Kuzari'de yer alan felsefeye yönelik ifadelerdeki farkl1lıkları büyük ölçüde açıklamaktadır.

Konu üzerine bir makalesi bulunan Michael S. Berger ise üslûp ve kurgunun ötesinde daha geniş bir perspektiften Kuzarìye bakmayı önermektedir. Berger'a göre -Saîd el-Feyyûmî (Saadya Gaon), Abraham İbn Dâvûd ve İbn Meymûn gibi Yahudi âlimlerden farklı olarak- Halevinnin temel meselesi Yahudilik ile Grek felsefesi arasındaki gerilimi çözüme kavuşturmak değildir. Esasen Halevi gelenekçi çizgiyi temsil etmekle birlikte, ne iman lehine aklı tamamen reddetmekte ne de Aristocu Yahudi âlimlerin yapt1$\breve{g}_{1}$ gibi bu iki geleneği uzlaştırmaya çalışmaktadır. Dinî hakikate ulaşmada felsefenin yani dinî pratikten bağımsız bir akıl yürütmenin (klyas) işlevsiz ve geçersiz olduğunu öne sürmektedir. ${ }^{45}$ Fakat Berger’a göre, Karâi filozofa yönelik reddiye üzerinden felsefenin işlevsizliğini göstermenin ötesinde Halevỉnin burada yapmaya çalıştığı asıl şey, dinî şiirlerinde işlediği konuyu yani Filistin topraklarının Yahudiler için merkezî konuma sahip olduğunu teolojik-entelektüel zemine taşımaktır. Buna göre Halevi’nin nihaî amacı, Müslüman-Arap kültürünün ve dolayısıyla Grek felsefesinin etkisi altında bulunan ve İspanya’yı anavatanları olarak gören İspanya Yahudi cemaatinin elit kesimine, benimsemeleri gereken kültürün otantik Yahudi kültürü, asıl vatanlarının da Filistin olduğunu göstermektir. ${ }^{46}$ Diğer bir ifadeyle Halevi, dindaşlarına, "Arapçılık" (el-Arabiyye) yerine "İbrânîcilik"i (el-'̇́brâniyye) benimseme, bunun için de Grek akılcılığını temsil eden Atina’dan -yani dönemin Atina’sı konumundaki Endülüs'ten- Yahudi vahyini temsil eden Kudüs'e dönme çağrısında bulunmaktadır. ${ }^{47} \mathrm{Bu}$ çağrı, sadece düşünce biçimi olarak değil aynı zamanda coğrafî olarak da dönüşü içermektedir. Esasen bu hedef, tıpkı kitabın sonunda hahamın yaptığı gibi bizzat Halevỉnin de Filistin

44 Silman, Philosopher and Prophet, s. 9-12, 169; ayrıca bk. Berger, “Toward a New Understanding of Judah Halevi's 'Kuzari”, s. 214; krş. Pines, "Shī'ite Terms and Conceptions in Halevi's Kuzari”, s. 218-19, dn. 290.

45 Berger, “Toward a New Understanding of Judah Halevi's 'Kuzari”, s. 219.

46 Berger, “Toward a New Understanding of Judah Halevi’s 'Kuzari”, s. 219 vd.; ayrica bk. Hughes, "The Use of Dialogue in Halevi's Kuzari", s. 477.

47 Cohen, "Rosenzweig's Rebbe Halevi”, s. 454. Grek felsefesi ile İbrânî vahiy geleneğinin birbirine taban tabana zıt iki dünya görüşü olduğunu ifade etmek için yapılan Atina-Kudüs karşılaştırması erken Hıristiyanlık dönemine kadar geriye gitmektedir (III. yüzyılda yaşamış Hıristiyan ilâhiyatçısı Tertullian' in, heretiklere karşı yazdığı, "De praescriptione hereticorum" adlı risâlesinde yer alan "Kudüs’ün Atina ile işi ne?” mealindeki sorusu). Bununla birlikte akıl-vahiy zıtllğını temsil eden "Atina-Kudüs" ifadesi bilhassa Aydınlanma döneminde öne çıkmıştır. 
topraklarına gitme kararı almasında bâriz biçimde görülmektedir. Bu noktada Kuzari'deki haham karakterinin ve sergilediği görüşlerin Halevi ve fikirleri ile ne derece özdeş kabul edilip edilemeyeceği de tartışmalıdır. Bu özdeşliği neredeyse tamamen reddeden uç görüşler mevcuttur. ${ }^{48}$ Aslında Halevi ile haham arasında birebir özdeşlik kurmak yerine Halevi’nin, farklı dönemlere ait olan kendi görüşlerini kimi zaman hahama, kimi zaman da Hazar kralına (ve hatta Aristocu filozofa) söylettiğini düşünmek daha isabetlidir. ${ }^{49}$

Öte yandan Halevi’nin Filistin'e gitme kararı almasının ardındaki sebebin şahsî dindarlık mı yoksa mesihî kurtuluş beklentisi mi olduğu konusunda da farklı görüşler ileri sürülmüştür. Samuel Cohon, söz konusu sebebin sadece şahsî dindarlıkla açıklanamayacağı, bunda mesihî kurtuluşu sağlamak için Yahudiler'i Filistin'e dönmeye teşvik etme düşüncesinin de etkili olduğu şeklindeki görüşe işaret etmektedir. ${ }^{50}$ Cohon tarafından dikkat çekildiği üzere, Halevi Kuzari'de, hahamın ağzından, İkinci Mâbet döneminde kutsal topraklara dönüş vaadinin tam olarak gerçekleşmemesini, sürgün Yahudileri’nin çoğunluğunun ve özellikle de elit kesimin Bâbil'deki sürgün hayatını tercih etmesine ve Filistin'e dönmek istemeyişine bağlamaktadır. ${ }^{51}$ Yine haham Kuzari’nin sonunda "Kudüs ancak, İsrâiloğulları bu şehrin taşları ve toprağı için hasret çekecek kadar iştiyakla ona arzu duydukları zaman (yeniden) kurulur" demektedir. ${ }^{52}$ Bu mânada Halevi’nin Endülüs Yahudi cemaatinin elit kesimi ile Bâbil sürgün cemaatinin elit kesimi arasında özdeşlik kurduğunu düşünmek isabetlidir. Berger'a göre Halevi, İspanya Yahudi cemaatinin elit kesimini İbrânîce yazdığı şiirler yoluyla duygusal olarak, Arapça yazdığ $1 \mathrm{Ku}$ zari yoluyla da felsefî olarak etkilemek istemiştir. Bu şekilde, Siyon üzerine yazdığ 1 şiirleri ile Kuzari, hedefleri itibariyle birbirini tamamlamaktadır. ${ }^{53}$

48 Micah Goodman, The Dream of the Kuzari'sinde bu yönde görüş ileri sürmektedir.

49 Bununla birlikte Halevi, Kuzari’nin başında (1:1), "Bu hahamın delillerinden (birçoğu) bana ikna edici ve düşünceme uygun geldiğinden, bu delilleri olduğu gibi kaydetmeye karar verdim ki ârif olanlar anlar” demek suretiyle hahamın bütün görüşlerini benimsemediği imasında bulunmaktadır.

50 Bk. Cohon, "Jehuda Halevi”, s. 465. Cohon, Halevi’nin yaşadığı çağda mesihî beklentilerin (bilhassa 1068 ve 1096 yıllarına yönelik olarak) ve hatta mesih iddiasında bulunanların mevcudiyetinden bahsetmekte; özellikle de Halevi’nin ölümünden kısa süre sonra 1147'de David Alroy'un kendisini mesih iddia ettiğine işaret etmektedir. 1147 Muvahhidler'in Endülüs'ün yönetimini ele geçirdiği yıl olmaktadır (bk. "Jehuda Halevi", s. 46o-61).

51 el-Kitâbüll-Hazerî, 2:24; 5:27; ayrıca bk. Cohon, "Jehuda Halevi”, s. 465. Makale boyunca Kuzari'den yapılan bütün alıntılar, Nebîh Beşîr' in Arapça neşri (el-Kitâbü’l-Hazerî) ile Yosef Kafih’in (veya Kafah) Arapça-İbrânîce neşri (Sefer ha-Kuzari) esas alınarak tarafımızdan yapılan tercümeye dayanmaktadır.

52 el-Kitâbül-Hazerî, 5:27.

53 Berger, “Toward a New Understanding of Judah Halevi’s 'Kuzari”, s. 219. 
Halevỉnin Kuzari'de sergilediği bu gelenekçi ve aynı zamanda mesihçi tavrın, Endülüs'teki “Yahudi altın çăğ’nın (755-1300) son ve çalkantılı döneminde yaşamış olması ve Yahudiler'in İspanya topraklarındaki geleceğinden kaygı duymasıyla bağlantılı olduğu açıktır. Zira Endülüs Yahudileri, 1090 y1lında bölgeye hâkim olan Murâbitlar döneminden itibaren eski rahat konumlarını kaybetmeye başlamışlardır. Halevỉnin ölümünden birkaç yıl sonra bölgenin yönetimini ele geçiren Muvahhidler'in döneminde ise din değiştirme baskısıyla karşı karşıya kalmışlardır. Hıristiyan İspanya’da ise başlangıçtaki görece tolerans ortamının ardından baskı ve kıyımla karşılaşmışlardır. Fakat bütün bu gelişmelere rağmen Müslüman kültürün Endülüs Yahudileri üzerindeki etkisi Halevi'den sonra da devam etmiştir. Esasen bu etkinin en önemli tezahürünü İbn Meymûn'un şahsında görmek mümkündür. ${ }^{54} \mathrm{Fa}-$ kat bu noktada Berger, Halevi'yi çok fazla muhatap almadığı anlaşılan İbn Meymûn'a değil,$^{55}$ Halevi ile çağdaş olan bir diğer Endülüslü Yahudi düşünür Abraham b. Dâvûd’a, özellikle de İbn Dâvûd'un, tıpkı Halevi gibi, Karâî iddialarına karşı Rabbânî Yahudiliği savunmak maksadıyla kaleme aldığı Sefer (veya Seder) ha-Kabbala (1160-1161) adlı kitabına dikkat çekmektedir. İlk Aristocu Yahudi filozofu olan ve belli noktalarda İbn Meymûn’u da etkilediği kabul edilen İbn Dâvûd, ${ }^{56}$ Mûsâ peygamberden itibaren kesintisiz biçimde nakledilen Rabbânî ilim geleneğini anlattığı kitabının önemli bir kısmını İspanya Yahudi ilim geleneğine ayırmış, Endülüs Yahudi cemaatinin varlığına Muvahhidler tarafından son verilmesine rağmen Hıristiyan kontrolündeki Toledo’da yeni bir Yahudi ilim merkezinin oluşturulduğuna işaret etmiştir. ${ }^{57}$ Sefer ha-Kabbala’nın neşrini yapan Gershon Cohen’in tespitine göre İbn Dâvûd bu kitabını, Halevi’nin, Endülüs'ten Kudüs'e dönmeleri için İspanya Yahudileri’ne yaptığı çağrıya bir cevap olarak ve temsil ettikleri Endülüs geleneğine olan güvenleri Halevi yüzünden sarsılan İspanya Yahudileri’nin özgüvenlerini tazelemek adına yazmıștır. ${ }^{58}$ İbn Dâvûd’un, Aristocu Müslüman filozoflar olarak bilinen Fârâbî ve İbn Sînẩnın görüşlerini Yahudi düşüncesiyle entegre etmek adına kaleme aldığı ve Aristo felsefesi ile Yahudiliği

54 İbn Meymûn'un düşünce sisteminin büyük ölçüde Yahudi dışı kaynaklardan, özellikle de İslâm filozoflarının görüşlerinden etkilendiği hususuyla ilgili olarak bk. Pines, “Translator's Introduction”, s. lvii-cxxxiv; ayrıca bk. Kreisel, “Judah Halevi’s Influence on Maimonides", s. 95-96, 102.

55 Halevi’nin İbn Meymûn üzerindeki muhtemel ve fakat zımnî etkisine yönelik değerlendirme için bk. Kreisel, "Judah Halevi's Influence on Maimonides", s. 102-21.

56 Söz konusu etki için bk. Fontaine, "Was Maimonides an Epigone?”.

57 Fontaine, "Ibn Daud", s. 662.

58 Bk. Berger, "Toward a New Understanding of Judah Halevi's 'Kuzari”'s. 216-17. İbn Dâvûd'un bu kitabını Kuzari'ye bir cevap olarak yazdığına başka araştırmacılar da işaret etmiştir. Bk. Hirschfeld, "Introduction”, s. 24; Fontaine, "Ibn Daud”, s. 663. 
uzlaştırmaya yönelik ilk sistematik çaba şeklinde nitelenen bir diğer kitabı $\mathrm{el}$ Akỉdetür-râfía (1168), İbrânîce adıly ha-Emuna ha-Rama'nın da, Halevi’nin Kuzari'deki felsefe eleștirisine dolaylı yoldan bir cevap olarak yazıldığı kabul edilmektedir. ${ }^{59}$ Dolayısıyla İbn Dâvûd'un, her iki kitabı üzerinden Halevi’nin iddialarına cevap verme çabası, Halevi’nin Kuzarisinin kendi döneminin İspanya Yahudileri üzerinde etkili olduğunu göstermektedir.

Halevi'nin, Yahudiler'i felsefenin etkisi altındaki çevre kültürden (Atina/ Endülüs) otantik vahiy geleneğine yani Yahudiliğe (Kudüs) çekme konusunda tam olarak başarılı olduğundan söz etmek güç olsa da hem çağdaşları hem de kendinden sonra yaşamış çeşitli Yahudi âlimler üzerinde bir etki oluşturduğu kesindir. ${ }^{60}$ Belki bundan daha da fazla Halevi'nin, hem şiirleri hem de Kuzarisi yoluyla modern Yahudiler, özellikle de dindar siyonistler üzerindeki etkisine işaret etmek gerekmektedir. ${ }^{61}$

\section{Kuzari'de Yahudilik Savunusu ve İslâm Eleștirisi}

Yukarıda işaret edildiği üzere Halevi, Kuzarisinde, temelde Yahudilik savunusu yapmakta, bunu yaparken de Rabbânî Yahudiliğe rakip konumda gördügü düşünce ve inanç sistemlerini eleştirmektedir. Hedef aldığı grupların başında da bilhassa filozoflar (Aristocular), kelâmcılar ve içeriden bir grup olarak Karâ̂ler gelmektedir. ${ }^{62} \mathrm{Bu}$ üç grubun ortak özelliği büyük ölçüde Müslüman coğrafyanın ürünü olmaları ve ilk iki grup itibariyle de ağırlıklı olarak Müslüman âlimlerden oluşmalarıdır. Dolayısıyla Kuzarideki

59 Bk. Fontaine, “Ibn Daud”, s. 663.

6o Kuzarỉnin, yazımının üzerinden yarım asır bile geçmeden İbrânîce’ye çevrilmesi ve Halevi sonrası Ortaçağ Yahudi âlimleri üzerindeki etkisiyle ilgili olarak bk. Hirschfeld, "Introduction", s. 23-28.

61 Kuzarìnin İbrânîce’ye tercüme edildiği dönemden modern döneme kadar farklı Yahudi âlimler üzerindeki etkisine yönelik kapsamlı bir çalışma için bk. Shear, The Kuzari and the Shaping of Jewish Identity; ayrıca bk. Kaplan, "Judah Halevi as Philosopher, Poet, and Pilgrim", s. 97-132; krş. el-Kitâbü'l-Hazerî, s. 12-13 (Mütercimin takdimi). Halevi'nin felsefe eleştirisinin ve dinî tecrübeye yaptığı vurgunun bilhassa Franz Rosenzweig ve Martin Buber gibi Yahudi varoluşçular üzerindeki etkisine sıkça işaret edilmiştir. Bu konuda yapılmış çalışmalara örnek olarak bk. Cohen, "Rosenzweig's Rebbe Halevi", s. 448-66; Birnbaum, "Judah Halevi and Martin Buber on the Radicalization of Judaism”, s. 391-40o. Öte yandan Halevi’nin görüşlerinin, Yahudi Aydınlanması'nın öncülerinden olan Moses Mendelssohn'un Yahudilik anlayışına etkisine de işaret edilmiştir (bk. Shear, The Kuzari and the Shaping of Jewish Identity, s. 230-35). Nihaî hedefleri farklı olsa da, Mendelssohn'un, akıl yoluyla ulaşılan evrensel "insanlık dini”nden ayrı olarak "vahyedilmiş şeriat" şeklinde tanımladığı ve Yahudi topluluğuyla sınırlandırdığ Yahudilik anlayışı ile Halevỉnin dışlayıcı ya da öznel Yahudilik anlayışı arasındaki benzerlik dikkat çekicidir.

62 Hirschfeld, "Introduction", s. 5. 
eleștirinin temel hedefi, İslâm filozofları yoluyla yükselişe geçen ve İspanya'daki Yahudi âlimleri de etkisi altına alan Grek felsefesi (bilhassa Aristoculuk), Müslüman kelâm geleneği ve yine Müslüman coğrafyada (Irak) mezhepleşme sürecine girmesine paralel olarak genelde İslâm geleneğinden özelde ise kelâm geleneğinden etkilenen Karâîlik olmaktadır. ${ }^{63}$ Yine en başta işaret edildiği üzere, Halevinnin Müslüman Arap kültürünün etkin olduğu bir coğrafyada yetişmiş olması sebebiyle Kuzari'de kullandığ 1 terminoloji de büyük ölçüde İslâmî kavramlardan beslenmektedir.

Aslında Kuzari'deki Yahudilik savunusu ile İslâm eleştirisini de birbirine paralel görmek gerekmektedir. Halevi çoğu zaman, farklı bahisler üzerinden Yahudilik ile İslâm arasında karşılaştırma yapmakta ve bu karşılaştırmanın temel noktasını seçkincilik-evrensellik ilişkisi ya da daha doğru ifadeyle karşıtlığı oluşturmaktadır. Son derece isabetli görünen bu karşılaştırma Yahudiliğin belli bir soyu ve kavmi esas alan seçkinci-dışlayıcı yapısına karşllık, İslâm’nn, ümmet vurgusu bir yana, daha ziyade fert eksenli ve evrensel-kapsayıcı özelliğe sahip bir din oluşu üzerine temellenmektedir. İslâm açısından Yahudiliğin kavim temeline oturuyor olması, bu dinin mesaj ve misyon olarak, en basit ifadeyle, sinırlı olduğu anlamına gelmektedir. Halevi için ise Yahudiliğin temelinde yatan bu soy unsuru, tam aksine, Yahudi dininin otantikliğinin ve hakikatinin, buna bağlı olarak da üstünlügüüün ölçüsü ya da göstergesi olmaktadır. Dolayısıyla Halevi’nin Yahudilik savunusu bilhassa İslâm’la kurulan söz konusu karşıtllk ve üstünlük iddiası üzerine temellenmektedir. ${ }^{64}$

\subsection{Dinî Hakikatin Ölçüsü Olarak Yahudi Vahyi}

Epstein’ın ifadesiyle Kuzari’nin çıkış noktasını oluşturan, "Dinî hakikatin ölçüsü nedir?” sorusuna Halevi’nin verdiği cevap, dinin mantıktan ve nazariyeden, dolayısıyla zihnî çabadan bağımsız olarak kendi kaynağına yani vahye sahip olduğu şeklindedir. ${ }^{65} \mathrm{Bu}$ noktada Halevi, genel geçer bir ölçü-

63 Hirschfeld, Karâîler'in, reddettikleri Rabbânî gelenek yerine kelâm geleneğini ikame etmeye çalıştıklarına işaret etmektedir. Bk. "Introduction", s. 3. Ayrıca bk. el-Kitâbü’lHazerî, 5:15-16.

64 Kuzari'de İslâm kadar olmasa da Hıristiyanlığa yönelik de ciddi eleştiriler yer almaktadır. Esasen Kuzarinin, kısmen Petrus Alfonsỉnin hem Yahudiler'i hem de Müslümanlar’ı hedef alan polemik kitabına cevap niteliğinde olduğu kabul edilmektedir (bk. Cohon, "Jehuda Halevi”, s. 458). Alfonsi'nin 1110 yılında Latince kaleme aldığ 1 reddiyesi bir Yahudi ile bir Hıristiyan arasında geçen diyaloğa dayanmaktadır. Alfonsi ve reddiyesi hakkında bilgi için bk. Meral, "Petrus Alfonsi’nin 'Yahudilere Reddiye’sinde İslam Eleştirisi”, s. 173-92.

65 Epstein, “Judah Halevi as Philosopher", s. 205 vd.; ayrıca bk. el-Kitâbü’l-Hazerî, 1:13-25. 
den (akıl) hareketle hakikat tanımı yapan ve bu ölçüye göre Yahudi dinini yorumlayan akılcı Yahudi düşünürlerden temelde ayrışmaktadır. Halevi, hakikat tanımının merkezine akıl yerine diğer monoteist dinler için de geçerli olan vahiy kavramını koymakla birlikte, daha ziyade Yahudi dininin kendi özelliklerinden hareketle ve dolayısıyla öznel bir dinî hakikat tanımına ulaşmaktadır. ${ }^{66}$ Özellikle Kuzari’nin başında yer alan, Hazar kralının diğer grupların temsilcileriyle yaptığı kısa diyalogların ya da gıyabî münazaranın, söz konusu öznel hakikat tanımını oluşturmak üzere kurgulandığ1 görülmektedir. Esasen Kuzari'nin bütün kurgusu bu amaca hizmet etmektedir. Halevi'nin hedeflediği sonuç doğrultusunda, Hazar kralı sorulması istenen soruları sormakta, muhatapları da verilmesi istenen cevapları vermektedir. Yahudi dininin kendi özelliklerini dikkate alma ve içeriden bir bakış sergileme bakımından Halevi'nin tam anlamıyla gelenekçi çizgiyi temsil ettiğini söylemek mümkündür. Fakat aşağıda temas edileceği üzere, Halevi’nin ortaya koyduğu bilhassa seçilmişlik anlayışının Yahudi geleneğini birebir yansıtmadığg ve gelenek açısından da bir daralma anlamına geldiği de çeşitli Yahudi yazarlar tarafından vurgulanmıştır.

Halevi'ye göre Yahudiliğin gerek felsefeye gerekse diğer dinlere üstünlüğü, sahip olduğu öz(n)el vahiy tecrübesine ve geleneğine dayanmaktadır. Halevi'nin burada özellikle atıfta bulunduğu vahiy, Mûsâ peygamber arac1lı̆̆ında ve topluluk halinde gerçekleşen Sînâ vahyidir. Halevi’ye göre, Yahudi vahyinin temelini oluşturan Sînâ vahyi, diğer dinlerin vahiy biçimlerinden farklı olarak, bütün bir kavmin yani İsrâiloğulları'nın tanıklığında ve hatta iştirakiyle gerçekleşmiş olması (yani Tanrı'nın kendisini ya da iradesini bütün bir topluluğa izhar etmesi) sebebiyle tam bir vahiy özelliği taşımaktadır. ${ }^{67}$ Bu noktada Halevi bilhassa, Tevrat'ta anlatıldığı üzere, Sînâ ahdinin özünü oluşturan On Emir'in veriliş biçimine atıf yapmaktadır. Tanrı ile ahitleşmek üzere Sînâ dağının eteklerinde toplanan İsrâiloğulları’nın On Emir’i oluşturan ilâhî hitabı, "tek tek kişilerden veya peygamberden değil, bizzat Allah’tan" işittiklerini ve bununla kalmayıp aynı zamanda "ahit levhalarına yazılmış ilâhî yazı"yı gördüklerine dikkat çekmektedir. ${ }^{68}$ Halevi'nin burada

66 Bk. el-Kitâbü'l-Hazerî, 1:26-27.

67 Halevi'ye benzer şekilde İbn Meymûn, Sînâ vahyini en üst düzey vahiy şeklinde tanımlamaktadır. Fakat Halevi’ye göre bu vahyin üstünlüğü topluluk halinde gerçekleşmesine dayanırken İbn Meymûn'a göre ise daha ziyade Mûsâ peygamberin ayrıcalıklı konumundan, yani Tanridan aracısız olarak vahiy almasından kaynaklanmaktadır (bk. Delâletü'l-hâirîn, 2:33-35).

68 "Kavim (Allah’ın) konuşmasını da açık biçimde, hükümlerin aslını ve temelini oluşturan On Emir şeklinde işittiler" (el-Kitâbü̉l-Hazerî, 1:87). On Emir'in verilişi noktasında (bilhassa Tanrı tarafından bütün kavmin duyabileceği şekilde vahyedilen ilk iki emirle bağlantılı olarak) İbn Meymûn, İsrâiloğulları’nın sadece güçlü bir ses duyduğunu, 
Hıristiyanlar’ın ve Müslümanlar’ın vahiy biçimlerini hedef aldığı açıktır. Her iki gelenekte de vahiy, önce ilgili peygambere/elçiye ulaşmakta, peygamber/ elçi tarafından inananlara sözlü olarak aktarıldıktan sonra yakın veya uzak bir zamanda insan eliyle yazıya geçirilmektedir. Gerçi Sînâ vahyinin farkl1lığı da aslında sadece On Emir'in vahyediliş biçiminde ortaya çıkmaktadır. Tevrat'ın geri kalan kısmının vahyedilişinin, Tanrı’nın Mûsâ ile yüz yüze konuşması hariç, en azından Kur'an vahyinden önemli bir farka sahip olmadığı görülmektedir. Fakat, anlaşıldı̆̆ı kadarıyla Halevi’ye göre, On Emir’in verilişi sırasında İsrâiloğulları’nın bu hadiseye bizzat tanıklık etmeleri, yani On Emir'in sözlerini bizzat Tanrı'dan işitmeleri, Tanrı’nın Mûsầya aracısız biçimde ilettiği Sînâ vahyinin tamamını, inkârı mümkün olmayan bir vahiy konumuna çıkarmaktadır. Zira Halevi’nin ifadesiyle, "Bu hadiseye şahit olan herkes bu işin Yaratıcı tarafından aracısız gerçekleştiğine kanaat getirmişlerdir.” Buna göre Halevi’nin vahiy anlayışının merkezinde, doğru bilginin ötesinde dinî tecrübe yer almaktadır. ${ }^{69}$ Halevi ayrıca Sînâda vahyin verilişi ile dünyanın yaratılışı arasında benzerlik kurmaktadır: "Allah, tıpkı gökleri ve yıldızları sırf kendi dilemesiyle yarattı̆̆ gibi iki levhayı yarattı ve üzerlerine yazı nakşetti (...) herhangi bir alete veya aracı sebeplere ihtiyaç duymadı (...) Bu şekilde fertlerde (...Allah’ın) iki levhayı (...) ve diğer şeyleri tasarlayıp yarattı̆̆ı gibi (...) dünyayı da yaratmış olduğuna yönelik iman hâsıl oldu; böylece filozoflara ve materyalistlere (dehriyye) ait şüpheler müminin zihninden zâil oldu."70

Halevi'nin yaptığı bu karşılaştırmaya göre peygamberlerin sahip olduğu bilgi yani vahiy doğrudan Tanrı'dan geldiği ve tecrübeye ya da müşahedeye dayandığ be yerine akla ya da kıyasa yani spekülasyona dayanması sebebiyle şüphe içermektedir. ${ }^{71}$ Bu noktada Halevi, aklî kesinliği tamamen reddetmemekle

Tanrı ile aracısız konuşan Mûsâ peygamberin ise birebir kelimeleri işittiğini söylemektedir (bk. Delâletü'l-hâirîn, 2:33). Halevi ise bu noktada Mûsâ ile İsrâil kavmi arasında hiçbir fark görmemekte ve bu hadiseyi toplu vahiy şeklinde değerlendirmektedir. Fakat bu tecrübeye muhatap olmak için gerekli olan kuvvet sadece Mûsâda mevcut olduğundan, vahyin geri kalanı için Mûsẩnın aracılığını talep ettiklerine de işaret etmektedir (bk. el-Kitâbül-Hazerî, 1:87).

69 Bk. el-Kitâbül-Hazerî, 1:25; ayrıca bk. Wiener, "Judah Halevi’s Concept of Religion", s. 670 .

70 el-Kitâbü'l-Hazerî, 1:89, 91. Makale boyunca Kuzari'den yapılan doğrudan veya dolaylı alıntılarda Kuzari'de kullanılan orijinal ifadeler italik olarak parantez içinde gösterilmiştir.

71 "Haham: (...) bizim hükümlerimiz, Allah’ın Mûsâyya (doğrudan) bildirmesi ve Mûsânın (bunu) yazıya geçirip Tih (çölün)de toplandığı sırada bu büyük topluluğa iletmesi suretiyle Tevrat'ta sıralanmıştır. Tevrat'ta tek tek sûrelerin veya âyetlerin isnadını 
birlikte bunun matematik alanıyla sınırlı olduğunu, felsefe/ilâhiyat alanı için geçerli olmadığını ileri sürmektedir. Zira Halevi’ye göre felsefenin cevap aradiğı sorular (Tanrı, yaratılış, mebde ve mead konuları) akılla değil vahiyle cevaplanabilecek sorulardır. Bu sebeple vahiy akıldan, vahye muhatap olan peygamber de filozoftan üstün olmaktadır. ${ }^{72}$ Halevi’nin matematik ilmi ile ilâhiyat ilmi arasında ön gördügü ayırım ve dinî hakikat konusunda tecrübeye/müşahedeye yaptığı vurgu, çeşitli araştırmacılar tarafından işaret edildiği üzere, Gazzâlî̉nin bilhassa Tehâfütü’l-felâsife'de (1095) ortaya koyduğu görüşlerin neredeyse birebir tekrarı olmaktadır. ${ }^{73}$

Halevi'ye göre Yahudi vahyinin bir diğer hususiyeti ise İsrâiloğulları'nın toplu olarak tecrübe ettiği Sînâ vahyine ait hükümlerin yani Tevrat'in da, kesintisiz bir gelenek (isnat) yoluyla sonraki nesillere aktarılmasıdır. Bu noktada Halevi, Sînâdaki toplu vahiy tecrübesinin ve aynı şekilde toplu isnada yani bir nevi tevatüre dayanan Rabbânî geleneğin hata ya da yanılgı ihtimalini ortadan kaldırdığını ileri sürmektedir ki bu görüş de büyük ölçüde Saîd el-Feyyûmînin Kitâbü'l-Emânât ve'l-i'tikādât'inda (933) ortaya koyduğu açıklamaya dayanmaktadır. ${ }^{74}$ Ayrıca burada Halevi'nin ve dolayısıyla Feyyûmînin, İslâm’ın isnat anlayışından ve aynı zamanda "sadık haber" kavramından beslendikleri anlaşılmaktadır. ${ }^{75}$ Dolayısıyla Halevi'ye göre, hem Sînâ vahyine bizzat muhatap olan İsrâiloğulları hem de onların ardından gelen Yahudi nesilleri kendilerine ulaşan/aktarılan bu tam vahiy sayesinde kesin bilgiye ve tam bir hakikate sahip olmaktadır. Buna karşılık filozofların ferdî akla ve spekülasyona (kıyas) dayanan argümanları ise şüphe içermektedir. ${ }^{76}$ Esasen Halevi’nin Karâîler'e yönelik en büyük eleştirilerinden biri, onların tıpkı filozoflar gibi, hakikate ulaşmada sahih geleneğe dayanmak yerine

belirtmeye ise gerek yoktur (...) Allah'a ibadet konusunda faraziye, akıl yürütme veya hükme varma yoktur. Eğer öyle olmuş olsaydı, filozoflar kendi hükümleri ve akıllarıyla İsrâiloğulları’nın ulaştığının iki katına ulaşırlardı" (el-Kitâbü’l-Hazerî, 1:99).

72 el-Kitâbül-Hazerî, 1:13, 63-65, 67; 2:56, 64; 3:53; 4:3, 15, 17; 5:12, 14.

73 Bk. Gazzâlî, Tehâfütü'l-felâsife, s. 76-77, 84-85; ayrıca bk. Lobel, Between Mysticism and Philosophy, s. 74-75; Hirschfeld, "Introduction", s. 6. Hirschfeld'e göre Halevi’nin görüşlerini tek bir cümleyle "verili iman lehine felsefeden şüphe duymak" şeklinde özetlemek mümkündür ve bu da "Gazzâlînnin görüşleriyle neredeyse özdeş olduğu" anlamına gelmektedir.

74 Halevi, hahamın ağzından ortaya koyduğu bu görüşü Kuzari’nin en başında Hıristiyan din âlimine de söyletmektedir. Bk. el-Kitâbül-Hazerî, 1:4; ayrıca bk. Feyyûmî, el-Emânât ve'l-ititikädât, s. 126-27.

75 Özellikle Feyyûmî, doğrudan "sadık haber" veya "sahih haber" ifadelerini kullanmaktadir.

76 el-Kitâbü'l-Hazerî, 1:65, 67, 88; 2:20, 64. Halevi, "kıyas" terimini, sahih geleneğe dayanan bilgi yerine akıl yürütme ve içtihatta bulunma yani felsefî spekülasyon yapma anlaminda kullanmakta ve kelimeye negatif bir mana yüklemektedir. 
ferdî içtihadı ve kıyası esas almaları ve bunun sonucunda dinî konularda fikir birliği sağlamak yerine fikrî anarşi durumuna düşmeleridir. ${ }^{77}$ Bu noktada Halevi vahyin taşıyıcısı ve muhafızı olarak gördüğü Rabbânî geleneğe bağlı kalmayı olumlu anlamda taklit şeklinde isimlendirmektedir. Gazzâlînnin ve diğer kelâmcıların taklide yükledikleri pejoratif mâna (körü körüne iman), Halevi'nin bilhassa Karâiler'in gelenek (yani sözlü Tevrat) karşıtı tutumuna cevaben ortaya koyduğu savunusunda tersine çevrilmektedir. Buna göre taklit, hakikatin önünde bir engel olmak yerine bilakis kalbin huzur ve sükûn bulmasını sağlayan bir durum olmaktadır. ${ }^{78}$

Halevi’ye göre filozofların dinî hakikate yönelik argümanlarında söz konusu olan şüphe ya da eksiklik gerek Hıristiyanlar’n gerekse Müslümanlar’n ferdî vahiy gelenekleri için de geçerlidir. Bu noktada Halevỉnin, Mûsâ sonrası İsrâil peygamberlerinin ferdî mahiyetteki vahiy tecrübeleri ile diğer iki dinin vahiy biçimleri arasında da fark gözettiği ve ilkinin, otantikliğini Sînâ vahyinden aldığ görüşünü benimsediği anlaşılmaktadır. Bu görüş bilhassa İbn Meymûn tarafından açıkça ifade edilmiştir. İbn Meymûn’a göre bir vahyin otantikliğinin ölçüsü, içerik olarak Mûsâ peygamberin vahyini yani Sînâ vahyini tasdik ediyor olmasıdır; bu tasdik de sadece Mûsâ peygamberden sonra gelen İbrânî peygamberlerin vahiyleri için geçerli olmaktadır. ${ }^{79}$

Halevi'ye göre dinî hakikatin akla değil vahye dayanıyor olması, Tanrı ile insan arasındaki dinî münasebeti ifade eden vahiy tecrübesinin ve dolayısıyla peygamberliğin de kişisel çabayla değil ancak Tanrı tarafından

77 Bk. el-Kitâbü'l-Hazerî 3:22-74; ayrıca bk. Lasker, “Judah Halevi”, s. 50o. Bununla birlikte Lasker, bazı konularda Halevi’nin Karâiler’ in görüşlerini benimsediğini ileri sürmektedir. Bunların başında da, muhtemelen Halevi’nin Filistin'e gitme kararında etkili olan, İsrail topraklarına dönmek suretiyle mesihin gelişini hızlandırma şeklindeki Karâî inancı gelmektedir. Lasker'a göre, Kuzari'deki Hazar kralının başlangıçta Karâî tarzı bir Yahudiliği benimsemiş olması da muhtemeldir. Esasen bu görüş Lasker'in, Kuzari'de ortaya konduğuna göre, kralın temsil ettiği mühtedi Yahudiliğiinin tedrîcîliği esas aldığ 1 şeklindeki teziyle de uyuşmaktadır (bk. Lasker, "Judah Halevi and Karaism”, s. 115-17; ayrıca bk. "Proselyte Judaism, Christianity, and Islam", s. 77 vd.).

78 Bk. Lobel, Between Mysticism and Philosophy, s. 77; ayrıca bk. el-Kitâbü'l-Hazerî, 3:37; 5:14; 4:25. Lobel, Kuzari'deki taklit kelimesinin, İbn Tibbon'un İbrânîce tercümesinde, "(sahih) gelenek" anlamındaki mesora ve kabala kelimeleriyle karşılandığına dikkat çekmektedir (bk. Between Mysticism and Philosophy, s. 211, dn. 116). Aslında taklit kelimesinin "gelenek" mânasındaki bu kullanımı da Gazzâlînin, meşru ve gayrimeşru taklit şeklindeki ayırımını çağrıştırmaktadır. Buna göre önceki âlimleri taklit etmek geçersiz, vahyi taklit etmek ise meşru kabul edilmektedir (bk. Özervarl, "Gazzâlî", s. 510) ki buradaki vahiy kavramıyla Halevi'nin gelenek kavramı arasındaki paralellik bârizdir. Gazzâlînin taklit konusundaki görüşleri için ayrıca bk. Frank, "Al-Ghazālī on Taqlīd", s. 207-52.

79 Moses Maimonides, “The Epistle to Yemen”, s. 111-13. 
başlatılabileceği anlamına gelmektedir. Tanrı, dilediği kişiyi kendisiyle bağlantı kurabilecek duruma yükseltmekte ya da bunun yolunu o kişiye göstermektedir. Filozofların iddia ettikleri gibi kişinin kendi zihnî gayretiyle ve Tanrı dışındaki aracı bir kuvvet (faal akıl) yoluyla ilâhlık âlemiyle bağlantı kurması söz konusu değildir. ${ }^{80}$ Dolayısıyla Tanrı̉nın inisiyatifine ve yol göstericiliğine dayanmayan bir dinî münasebet (vahiy/peygamberlik veya ibadet) iddiası, Halevi'ye göre bir yanılgıdan ibarettir. ${ }^{81}$ Esasen bu husus Kuzarinnin en başında yer alan Hazar kralının gördüğü rüya bahsinde açıkça ortaya konmaktadır. Rüyasında krala bir melek görünerek ona niyetinin sahih, ama amellerinin yani tuttuğu yolun yanlış olduğunu bildirmektedir. Bunun üzerine kral hakikat arayışına koyulmaktadır. ${ }^{82}$

Halevi, ayrıca, vahiy için gerekli gördügü ilâhî inisiyatifi sahih din anlamında Yahudiliğe de uygulamaktadır. Yine Kur’an'dan ödünç aldığı bir ifadeyi kullanarak, Yahudi dininin, tıpkı dünyanın yaratılmasında olduğu gibi Tanrı’nın "ol" emriyle defaten yaratıldığını belirtmektedir. ${ }^{83}$ Halevi’ye göre Yahudiliğin diğer dinlerden farkı da burada yatmaktadır. Bu durum, Yahudi dininin, beşerî bilgi ve düşünceye dayanan diğer rasyonel dinler gibi zaman içinde gelişerek değil (Halevi'ye göre bu tanım esasen filozofların din tanımıdır), ${ }^{84}$ bilakis Tanrı’nın dilemesiyle ve bir anda ortaya çıktığı; diğer bir

8o Halevi, bilhassa İbrâhim örneğinden hareketle emr-i ilâhî ile kurulan bu bağlantının felsefî spekülasyon (klyas) yoluyla değil dinî tecrübe/aşk (zevk) yoluyla gerçekleştiğini vurgulamaktadır (bk. el-Kitâbǜl-Hazerî, 4:17).

81 el-Kitâbü'l-Hazerî, 2:46, 48. Esasen Halevi, Mısır'dan çıkan İsrâiloğulları'ndan bir grubun işlediği altın buzağı ile ilgili günahı da bu çerçevede yorumlamaktadır. Haham tarafından ortaya konan açıklamaya göre İsrâiloğulları’nın bu hadisedeki asıl günahı suret yapmak ve ona tapmaktan ziyade, kendilerinin yaptığı bu surete Tanrı’nın buyruğu olmaksızın emr-i ilâhî ile bağlantı atfetmiş olmalarıdır: “(...) onlardan bir grup işi, kendilerini Mısır'dan çıkaranın ilâhlığını reddetmeksizin, diğer halklar gibi önder edinecekleri bir mâbut istemeye kadar vardırdı. Bu (mâbut) daha ziyade, Rablerinin (sergilediği) hârikulâdelikleri anlatacakları zaman gösterecekleri bir şey olacaktı; tıpkı Mûsầnın (as) sandığına inananların Rabb'in orada olduğunu söylemelerinde ya da bizim gökyüzünün ve her şeyin hareketinin tesadüfen veya insanın ya da tabiatın iradesiyle değil Allah’’n dilemesiyle olduğunu kabul etmemizde olduğu gibi. Onların hatası, kendilerine yasaklanan suret (oyma put) yapmaları ve sonra da Allah'ın iradesi (emr-i ilâhî) olmaksızın kendi elleriyle yapıp seçtikleri bu şeye ilâhî otorite (emr-i ilâhî) atfetmeleridir. Onların, aralarında ortaya çıkan bu anlaşmazlıktaki mazeretleri, toplam sayıları altı yüz bin olan topluluğun içinde bu (puta) tapanların sayısının üç bini geçmemesidir. Bu işe destek veren havâsın özrü ise âsilerin inananlardan ayrışmasını hedeflemeleridir ki böylece buzağıya tapan isyankârları öldürebilsinler" (el-Kitâbü’lHazerî, 1:97; ayrıca bk. Lobel, Between Mysticism and Philosophy, s. 192, dn. 43).

82 el-Kitâbüll-Hazerî, $1: 1$.

83 el-Kitâbü'l-Hazerî, 1:81; ayrıca bk. Yâsîn 36/82.

84 Halevi, daha sonra hahama söyleteceği bu tanımı en başta filozofun ağzından vermektedir. Bk. el-Kitâbül-Hazerî, 1:1. 
ifadeyle, Yahudiliğin ilâhî ve ezelî ya da zamansız olduğu, diğer dinlerin ise sonradan insan eliyle ve tedrîcen oluşturulduğu anlamına gelmektedir. Esasen bu iddia da Kur'an’nn, İslâm’ı ilk peygamber Âdem'den beri var olan ve bütün peygamberlerin tebliğ ettiği sahih din şeklinde tanımlamasıyla paralellik göstermektedir. Halevi’nin, bu şekilde, Kur’an’ın iddiasını alıp Yahudiliğe mâl ettiği ve İslâm’nn aleyhine kullandığı̆ görülmektedir. Fakat Halevi’nin, Yahudi dininin ortaya çıkışıyla alâkalı olarak ileri sürdügü bu iddia -yani ilâhî vasfı gereği tarihî sürecin dışında birdenbire ortaya çıktığı iddiası-, herhangi bir dinin (kökeni ister ilâhî ister beşerî kabul edilsin) bir toplum tarafından benimsenmesinin veya özümsenmesinin daima tedrîî̀ bir seyir takip ettiği ve bunun Yahudilik için de geçerli olduğu gerçeğini göz ardı etmektedir. Esasen modern dönemde Yahudi tarihine yönelik çalışmalar ve Yahudi tarihi üzerinden yapılan dönemlendirmeler, tedrîcîlik keyfiyetinin bilhassa Yahudilik için geçerli olduğunu göstermektedir. ${ }^{85}$

\subsection{Emr-i İlâhî ile Bağlantı ve Yahudi Seçilmişliği}

Halevi’nin, vahyin Tanrı’nın inisiyatifinde gerçekleşen bir durum olduğunu ifade etmek için kullandığı kilit kavram emr-i ilâhîdir. Kur'an'daki "emir" kelimesinden mülhem olan bu kavram, farklı araştırmacılar tarafından, Tanrı ile âlem arasındaki aracı güç veya unsur anlamında "logos" ile özdeşleştirilmiştir. Bu özdeşleştirmenin isabetli olmadığını düşünen Wolfson’a göre Halevi kimi zaman emr-i ilâhî kavramını farklı çağrışımlar yapacak şekilde kullansa da, bu ifadeyle kastettiği asıl mâna doğrudan Tanrı̉nın takdiri, iradesi, emri veya hikmetidir. ${ }^{86}$ Halevi'ye göre Tanrı ile insan arasındaki münasebet (vahiy) faal akıl veya logos gibi bir aracı güç olmaksızın doğrudan ilâhî emrin ya da ilâhî iradenin seçilmiş kişilere bağlanmasıyla ortaya çıkmaktadır. Bu bağlamda Halevi, ilâhî emrin seçilmiş kişilere (peygamberler, veliler vb.) ve hatta bütün İsrâil kavmine ittisalinden bahsetmektedir. ${ }^{87}$

Halevi'ye göre, İsrâiloğulları̉nın ve dolayısıyla peygamberlerin seçilmişliğinin temelinde yer alan emr-i ilâhî ile münasebet, en mükemmel insan (insân-1 kâmil) konumundaki Âdem'le başlamış, daha sonra Şit, Enoş, Nuh

85 Bk. Gürkan, Yahudilik, s. 17-22.

86 Wolfson, "Hallevi and Maimonides on Prophecy", s. 353-70. Halevi'nin emr-i ilâhî kavramını kullanımındaki muğlaklıkla ilgili olarak ayrıca bk. Kreisel, Prophecy, s. 136-40; Pines, "Shīite Terms and Conceptions in Judah Halevi's Kuzari", s. 171-80. Bu terim İbrânîce'ye ha-inyan ha-elohi (İbn Tibbon) veya ha-davar ha-elohi (Y. Kafih) şeklinde çevrilmiştir. Kuzarỉnin kimi yerinde emr-i ilâhî yerine irâde-i ilâhî ifadesi de geçmektedir.

87 Meselâ bk. el-Kitâbü'l-Hazerî, 1:4; 2:26, 50; 3:7, 23. 
gibi seçilmiş kişiler yoluyla Sam soyuna ve ardından seçilmiş İbrâhim soyuna yani İshak ve Yâkub'a ulaşmıştır. Yâkub'un oğulları olan on iki sıbt$\tan$ itibaren ise topluluk olarak İsrâiloğulları̀na intikal etmiştir. Halevỉnin, Âdem'in en şerefli ve saf soyu (lubâb-u Âdem ve safvetühĥu) diye tanımladığ İsrâiloğulları, bu şekilde, kendilerini yarı melek konumuna getiren ilâhî özelliklere sahip olmuşlardır. ${ }^{88}$ Halevi Sînâdaki toplu vahiy ve ahit tecrübesini, kadın-erkek bütün İsrâil kavmi âdeta Tanri’yla konuşma seviyesine yani bir nevi peygamber konumuna ulaşacak şekilde, emr-i ilâhînin topluluk olarak onların arasına inmesi ya da onlara yerleşmesi biçiminde tanımlamaktadır. ${ }^{89}$ Ayrıca bu özel konumları dolayısıyla hem Âdem için hem de ondan türeyen seçilmiş soy için "Tanrı’nın oğlu” (ibnullah) tabirini kullanmaktadır. ${ }^{90}$ Kısacası Halevi, birbirine paralel olarak kullandığı seçilmişliği ve peygamberliği Sam soyundan gelen İsrâiloğulları'na hasretmektedir.

Halevi'ye göre Âdem'den itibaren tevarüs edilen ve ilâhî desteğe mazhar olan ilim de sadece Nuh soyunun en seçkini olan Sam soyuna aittir ve tıpkı seçkinlik vasfı (safvet) gibi, tevarüs edilmiş olan bu ilmin de bu soydan ayrılması söz konusu değildir. Esasen Halevi’ye göre diğer milletlerin sahip olduğu ilimler de İsrâiloğulları yoluyla İbrânîce’den diğer milletlere -sırasıyla Bâbilliler'e, Persler'e, Grekler'e ve Romalılar'a- nakledilmiştir. ${ }^{91}$ Dolayısıyla sahip oldukları bilgi kendilerine Persler vasitasıyla intikal eden Grekler en meşhur filozoflarını Persler'i yendikten sonra yetiştirmişlerdir. Fakat en güçlü oldukları zamanda elde ettikleri bu bilgiyi Roma İmparatorluğu’nun siyasî hâkimiyeti ele geçirmesiyle birlikte kaybetmişlerdir. Bu noktada Halevi’nin bilgi ile siyasî güç arasında kurduğu ilişkinin yönü son derece ilginçtir.

88 Söz konusu melekî özellik Halevi tarafından bütün İsrâil kavmine atfedilirken İbn Meymûn ise bunu sadece Mûsâ peygambere atfetmektedir (bk. Delâletü'l-hâirîn, 2:3335; Moses Maimonides, Code of Maimonides, "Knowledge: Foundation of the Torah", $7: 2-6)$.

89 "(Bu ilâhî özellikler) âdeta onları melek cinsinden bir tür ve cevher kılmış, (bu şekilde) hepsi peygamberlik derecesini elde etmeye çalışmış ve içlerinden çoğu da bunu başarmıştır. Bunu başaramayanlar ise (işledikleri) makbul ameller, (sahip oldukları) kutsiyet, temizlik ve peygamberlerle görüşmüş olmaları sayesinde bu dereceye yaklaşmışlardır” (el-Kitâbü'l-Hazerî, 1:103).

90 el-Kitâbül-Hazerî, 1:95; 4:17.

91 el-Kitâbüll-Hazerî, 2:66. Bu noktada Halevi Sanhedrin'de her daim yetmiş üyenin bulunmasını her ilmi bilen üyelerin varlığının göstergesi şeklinde sunmaktadır ( $\mathrm{el}$ Kitâbüll-Hazerî, 2:63, 64). Ayrıca Halevi'ye göre İbrânîce, Âdem ve Havvảnın lisanı yani insanlığın ilk lisanıdır. Bu dil, lisanların farklılaşmasından sonra sadece Eber tarafından devam ettirildiği için onun adıyla (İbrânîce) anılmıştır (el-Kitâbü’l-Hazerî, 2:68). Yahudiler'in ilim konusunda üstün oldukları iddiasına karşı Semev’el el-Mağribînin getirdiği eleştiri için bk. İfhâmü’l-Yehûd, s. 14-15; Türkçe tercümesi için ayrıca bk. Yahudiliği Anlamak, s. 49. 
Bilginin elde edilişini siyasî güce bağlayan bu anlayış, tam tersi bir bakış açısıyla, Grekler'in, üstün filozoflara ve dolayısıyla üstün bilgiye sahip oldukları için Persler'i yenmiş olabilecekleri şeklindeki, vâkıaya daha mutabık görünen ihtimali göz ardı etmektedir. Burada Halevi’nin İsrâiloğulları'nın tevarüs ettiği ilim ile Grekler'in (veya Persler'in, Bâbilliler'in vb.) yani Yahudi olmayanların sahip olduğu ilim arasında esas itibariyle bir fark gözettiği anlaşılmaktadır. Buna göre ilki vahye dayanan ve sahih gelenek (taklit) yoluyla korunup sonraki kuşaklara aktarılan, dolayısıyla siyasî güçten bağımsız olan ilâhî bilgiye, ${ }^{92}$ diğeri ise akıl yürütmeye (kıyas) dayanan ve buna bağlı olarak kazanımı ve korunması siyasî güce bağlı olan beșerî bilgiye karşılık gelmektedir. Diğer bir ifadeyle, ilmin kendilerine vahiy yoluyla ulaştı̆̆ İsrâiloğulları’ndan farklı olarak diğer milletlerin bilgi elde etmeleri, siyasî üstünlüğe bağlı olarak bir topluluktan diğerine nakil yoluyla gerçekleşmektedir. Halevi'ye göre diğer milletlerin sahip olduğu bütün ilimler de köken itibariyle İsrâiloğulları́ndan nakledilmiş olsa da diğer milletlerin bu konudaki eksikliklerinin, bilgiyi doğru biçimde muhafaza edecek ve aktaracak sahih bir geleneğe sahip olmamalarından kaynaklandığ dır. Bu sebeple Halevi, Grek filozoflarının sahih geleneğe sahip olmadıkları için, vahiy hariç hakkında hiçbir kesin delil bulunmayan, dünyanın ezelî mi yoksa hâdis mi olduğu sorusuna akıl yürütme yoluyla cevap bulmaya çalıştıklarını ve neticede âlemin ezelî olduğuna hükmettiklerini söylemekte; bu sebeple bu çıkarımlarında mâzur olduklarını belirtmektedir. ${ }^{93}$ Buna karşılık şeriata sahip olan diğer din mensupları (el-muteşerriûn) yani Hıristiyanlar ve Müslümanlar ise, Halevi’ye göre, köken olarak Yahudiliğe yakın olmalarına rağmen, filozoflarla mukayese edildiğinde asıllarına yani Yahudiliğe daha

92 “Haham: 'Onu Tanrınız Rabb’in Ahit Sandığı’na koyun' dendiği üzere, ilmin kökü, kalbin yerini tutan sandığa konmuştur; o (kök) On Emir'dir, dalları da yanına uzanmış Tevrat'tır. Ondan iki ilim çıkmıştır: Şeriat ilmi Hârûnî imamlar (kohenler) tarafından taşınmaktadır; vahiy ilmi ise peygamberler tarafından. Bunlar(ın her ikisi de) tedvin ve yazıcılık yapan ümmeti uyaran özel danışmanlardır” (el-Kitâbü’l-Hazerî, 2:28).

93 el-Kitâbül-Hazerî, 1:63-67. Bu konuda oldukça temkinli davrandığı görülen Halevi, belki de ilk dönemki düşüncesinin sonucu olan akıl ile geleneği uzlaştırma refleksiyle, maddenin ve kezâ -varsa- başka âlemlerin ezelî olup olmadığg konusundan bağımsız olarak, en azından içinde yaşadığımız âlem söz konusu olduğunda geleneğin bu âlemi hâdis kabul ettiğini belirtmektedir: "Haham: (...) Şeriatın apaçık bilgiyi veya delili nakzeden bir şey getirmesinden Allah'a sı̆̆ınırım (...) Sonradan yaratılma (hades) fikri, Âdem, Nuh ve Mûsâ'dan (as) peygamberlik yoluyla aktarılmış (bilgiyi) esas alır ki bu yol akıl yürütmeden daha isabetlidir. Buna rağmen, şeriata bağlı olan bir kimse ezelî maddenin ve bu âlemden önce başka birçok âlemin var olduğunu kabul etme noktasına gelse bile, bu (kabul) onun bu dünyanın belli bir zamanda yaratılmış olduğuna ve bu dünyadaki insanların ilkinin Âdem ve Havva olduğuna yönelik inancına ters düşmeyecektir” (el-Kitâbü'l-Hazerî, 1:67). 
yabancılaşmış durumda bulunmaktadır. Bu noktada Halevi'nin Hıristiyanlar ve Müslümanlar ile İsrâiloğulları tarihinde ayrılıkçı kral olarak bilinen Yeroboam $^{94}$ arasında benzerlik kurması ilginçtir. Halevi'ye göre Yeroboam ve taraftarları İsrâiloğulları’ndan olmaları sebebiyle Mûsâ şeriatının çoğu uygulamasını (sünnet, sebt vb.) devam ettirmiş ama putlara taptıkları için, çölde buzağı heykeline tapan günahkâr İsrâiloğulları’nın durumuna düşmüşlerdir. Halevi’nin "müteşerrî” diye tanımladığı Müslümanlar ve Hıristiyanlar ise (burada daha ziyade Müslümanlar’’n kastedildiği anlaşılmaktadır) putlara tapmayı yasaklamaları sebebiyle Yeroboam'dan ehven olsalar da kıblelerini ve Yahudi şeriatına ait çoğu kuralı değiştirmeleri sebebiyle doğru yoldan uzaklaşmışlardır. ${ }^{95}$

Öte yandan Halevi'nin, emr-i ilâhî ile bağlantı kurma ayrıcalığını yani seçilmişliği belli kişiler yoluyla on iki sıbta, Kur'an'ın ifadesiyle esbâta uzanan bir hat üzerinden tanımlaması, özellikle de bu soyu Âdem'den başlatması Kur'an'ın peygamberlik anlayışının izlerini taşımaktadır. Kur'an'da Âdem'den ilk peygamber şeklinde bahsedildiği gibi, birbiriyle soy bağlantısı olan peygamberler de silsile halinde zikredilmektedir. ${ }^{96}$ İleride üzerinde durulacağ 1 üzere, seçilmiş silsileye atıf vurgusu Şiî İsmâilî yazarlarda da yer almaktadır. Fakat Kur'an anlayışından farklı olarak Halevi'nin tanımı, Tevrat'ta ortaya konan dışlayıcı seçilmişlik anlayışını devam ettirmek suretiyle İsmâil soyunu -ve aynı zamanda İsrâil soyundan olmayan diğer peygamberleribu kapsamın dişında tutmaktadır. Esasen Halevi’nin peygamberlik anlayışı dışlayıcılık boyutunu bir ileri noktaya taşımaktadır. Halevi’ye göre seçilmiş olma keyfiyetinin ve dolayısıyla peygamberliğin belli bir soy tarafindan tevarüs edilme özelliği, diğer toplulukları ve hatta bu topluluklar içinden Yahudi dinine girenleri de bu ayrıcalıklı konumun dışında bırakmaktadır. Bu noktada Halevi Yeni Eflâtuncu varlık sınıflandırmasına paralel olarak aşağıdan yukarıya doğru mineraller, bitkiler, hayvanlar ve insanlardan oluşan bir varlık hiyerarşisinden bahsetmektedir. Bu varlık grupları sırasıyla tabiî,

94 Tanah’ta yer alan bilgilere göre Kral Süleyman’n ölümünün ardından Yûsuf soyundan olan Yeroboam, kuzeydeki İsrâil kabilelerini kendi yönetimi altında bir araya getirmek üzere güneydeki Yehuda bölgesinin merkezi olan Kudüs'ten ve Kudüs'teki Mâbet’ten uzaklaşma siyaseti gütmüştür. Bu doğrultuda kuzeydeki İsrâil Krallığı’nın bulunduğu bölgenin iki ucuna, tıpkı günahkâr İsrâiloğulları’nın çölde yaptığı gibi, altından birer buzağı heykeli yerleştirmiş ve yeni mâbetler inşa ettirmiştir (I. Krallar, 12:25-33). Bu sebeple Yahudi geleneğinde Yeroboam, İsrâiloğulları tarihindeki ilk dinî-siyasî bölünmeyi başlatan kişi kabul edilmiştir.

95 el-Kitâbül-Hazerî, 4:13.

96 Meselâ bk. Âl-i İmrân 3/33: “Şüphesiz Allah, Âdem’i, Nuh’u, İbrâhim ailesini (soyunu) ve İmrân ailesini (soyunu) birbirinden gelmiş birer nesil olarak seçip âlemlere üstün kıldı." 
nefsânî ve aklî kanun tarafından yönetilmektedir. Seçilmiş soyu ifade eden peygamberler ise bu mertebelerin de üstünde yer alan ilâhî-melekî mertebede bulunmaktadır. ${ }^{97}$ Halevi'ye göre, söz konusu mertebe farkı sebebiyle, Yahudi dinini sonradan benimseyenler dahi saf soyun (surahâa ${ }^{98}$ yani doğuştan Yahudi olanların sahip olduğu iyiliklerden nasiplense de onlara denk olamamaktadır. ${ }^{99}$ Doğuştan Yahudiler'den öğrendikleri bilgi sayesinde ancak evliya veya ulemâ konumuna yükselebilmekte, fakat emr-i ilâhî ile bağlantı kurmayı gerektiren peygamber konumunu, dolayısıyla seçilmiş statüsünü elde edememektedir. ${ }^{100}$

$\mathrm{Bu}$ noktayla bağlantılı olarak Daniel Lasker, Halevi’nin, doğuştan Yahudiler'in dini olan "otantik Yahudilik" ve sonradan Yahudi olanların dini olan "mühtedi Yahudiliği” şeklinde bir ayırıma gittiğine işaret etmektedir. Lasker'in yorumuna göre, Hazar kralı örneğinde olduğu gibi tedrîcen öğrenilen mühtedi Yahudiliği, verili olan otantik Yahudilik ile Yahudiliğin bir nevi taklidi ya da kopyası olan diğer Sâmî-monoteist dinler yani Hıristiyanlık ile İslâm arasında ama otantik Yahudiliğe daha yakın bir konuma sahip olmaktadır. ${ }^{101}$ Yine Lasker tarafından dikkat çekildiği üzere, esasında

97 el-Kitâbül-Hazerî, 1:31-43.

98 Halevi’nin doğuştan Yahudiler'i ifade etmek için kullandığı sarîh/surahâ teriminin

Tanah'ta İsrâil sıbtlarına mensup olan doğuştan İsrâiloğulları için kullanılan ezrah kelimesi ile İsrâiloğulları’nın Tanrı̉nın has/kıymetli kavmi olduğunu ifaden eden segula $^{h}$ terimine karşılık geldiği anlaşılmaktadır. İlgili terimler için bk. Çıkış 12:48; 19:5; Levililer 16:29.

99 "Haham: (...) diğer milletlerden özel olarak (hâssaten) aramıza katılan kimse sadece bizim (sahip olduğumuz) iyiliklerden nasiplenir ama bize denk olmaz. Din (şeriat) (bize) yaratılmış olmamız sebebiyle şart kılınmış olsaydı, bu açıdan beyaz ile siyah da birbirine eşit olacaktı; zira ikisini de (Hak) Teâlâ yaratmıştır. Fakat din(in bize şart kılınması), Âdemoğulları'nın en seçkini olduğumuz için, O’nun bizi Mısır'dan çıkarması ve bizimle bağlantı kurması sebebiyledir" (el-Kitâbü'l-Hazerî, 1:27). Yahudi dinine girmekle bağlantılı olan bu cümlenin, bilhassa cümlede geçen hâssaten ifadesinin ve beyaz ile siyah benzetmesinin, "Benden önce her peygamber hassaten kendi kavmine gönderilirken, ben hem kırmızı hem siyah bütün insanlı̆̆a gönderildim” mealindeki hadîs-i şeriften hareketle söylendiğine işaret edilmiştir. Bk. Lobel, Between Mysticism and Philosophy, s. 36-37.

100 el-Kitâbül-Hazerî, 1:115. Rabbânî gelenekte yabancı topluluklardan çıktığına inanılan yedi peygamberin de, Halevi tarafından, peygamber yerine veli şeklinde değerlendirildiği anlaşılmaktadır. İbn Meymûn’a göre de, Mûsâ öncesi dönemde yabancı topluluklardan çıktığı kabul edilen peygamberler, İsrâil peygamberlerinin aşağısındaki bir statüde ve tam peygamber olmayan kişiler hükmünde değerlendirilmektedir (bk. Delâletüll-hâirîn, 2:32).

101 Lasker, "Proselyte Judaism, Christianity, and Islam", s. 78 vd. Buradaki "otantik Yahudilik" (Jewish Judaism) ve "mühtedi Yahudiliğii" (Proselyte Judaism) tabirleri Lasker’a aittir. Halevi sadece, doğuştan Yahudiler ve sonradan Yahudiliği seçenler şeklinde bir ayırım yapmaktadır: "İsrâil dinine (sonradan) giren yabancılar (ed-dahîl fî dîni 
Hazar kralının temsil ettiği mühtedi Yahudiliği, Halevi’ye göre, Yahudiliğin evrensel yönünü oluşturmaktadır. Halevi, Yahudiler'in mâruz kaldığı sürgün tecrübesi neticesinde, Yahudiliğe yani Mûsẩnın dinine, tıpkı tohumun toprağ1 dönüştürerek ağaç meydana getirmesi gibi, kendinden sonra gelen diğer dinleri dönüştürerek yani kendine benzeterek insanlı̆̆g mesihin gelişine hazırlama misyonu yüklemektedir. ${ }^{102}$ Lasker'in yorumuna göre, bu şekilde Yahudiler'in üstünlüğü ve farklılığı bâki kalmak şartıyla diğer din mensuplarının mühtedi konumuna, yani Yahudi olmaktan daha aşağı ama ona en yakın konuma gelmeleri amaçlanmaktadır. ${ }^{103}$ Halevi’nin, seçilmişliği doğuştan Yahudiler'e tahsis etmesine rağmen Yahudilik savunusu için mühtedi bir kralı (Hazar kralı) örnek olarak seçmesi de, esasen bu amaca hizmet etmektedir. Bu örnek aynı zamanda Yahudi dininin üstünlüğünü ispatlama noktasında mânevî ya da duygusal bir destek oluşturmaktadır. ${ }^{104}$

Halevi'nin seçilmişlik anlayışının bir diğer boyutu ise Filistin topraklarına atfedilen ayrıcalıklı konumdur. Halevi'ye göre emr-i ilâhî ile bağlantı kurabilmenin ilk şartı seçilmiş soya yani İsrâiloğulları’na ait olmak, ikinci

İsrâill), hâlis/saf olan (asıl)lara (es-sarîh) denk değildir" (el-Kitâbül-Hazerî, 1:115). Fakat Lasker’n yaptığı bu kavramsallaştırma, vâkıaya oldukça uygun düşmektedir.

102 el-Kitâbüll-Hazerî, 4:23.

103 Bk. Lasker, "Proselyte Judaism, Christianity, and Islam”, s. 86-91. Bu noktada Halevi’nin İsrâiloğulları’na ve dolayısıyla Yahudiler’e atfettiği üstünlüğün ırkçılık şeklinde okunup okunmayacağı konusunda da çeşitli yorumlar yapılmıştır. Yahudi araştırmacıların bu konudaki temel görüşü, Halevi’nin Yahudi seçkinciliğine yönelik tanımının biyoloji temelli olmadığı, dolayısıyla modern anlamda ırkçı ideolojilerle özdeşleştirilmesinin anakronik olacağı şeklindedir (söz konusu görüşler için bk. Bodoff, "Was Yehudah Halevi Racist?", s. 174-84; Dover, "The Racial Philosophy of Jehuda Halevi”, 312-22; ayrica bk. Lobel, Between Mysticism and Philosophy, s. 36-38). Halevi'nin, "bu ümmetin diğer ümmetlere olan münasebeti, kralın sıradan (ya da hükmü altındaki) insanlara olan münasebeti gibidir" (el-Kitâbül-Hazerî, 4:3) demek suretiyle, seçilmiş soy konumundaki Yahudiler ile Yahudi olmayanlar arasında tür değil, derece farkı gördüğü anlaşılmaktadır. Fakat burada söz konusu olan, derece farkına dayanan ve dinî mahiyete sahip bir üstünlük olsa bile, bu üstünlügün belli bir soy üzerinden ve doğuştan gelen bir özellik şeklinde tanımlanması ırkçılığa kapı aralayan bir durum arzetmektedir. Halevỉnin savunduğu bu üstünlük anlayışının modern ırkçı söylemle birleşmiş şeklini radikal dinî siyonizmde bulmak mümkündür.

104 Kreisel, Prophecy, s. 142. Halevi'nin kurgusuna göre başlangıçta Hazar kralı, düşük konumlarından dolayı, hakikatin Yahudiler'de olamayacağını düşünerek bir Yahudiye danışma ihtiyacı duymamış; fakat Hıristiyan ve Müslüman din âlimlerinin kendi dinlerinin doğruluğunu ispatlamak için İsrâiloğulları’na ve Tevrat'a atıf yapmaları üzerine İsrâiloğulları'nın devamı olan Yahudiler'e danışmay1 uygun bulmuştur: "Ben kendimi bu (konuyu) Yahudiler'e sorma mecburiyetinde hissediyorum; çünkü İsrâiloğulları’nın devamı olmaları sebebiyle onların, Allah’ın yeryüzünde bir şeriatı olduğunun bizâtihi delili olduğunu düşünüyorum” (bk. elKitâbül-Hazerî, 1:4-10). 
şartı ise seçilmiş topraklarda yani Filistin'de yaşamaktır. ${ }^{105}$ Dolayısıyla bu ayrıcalık hem belli bir soya hem de belli bir bölgeye bahşedilmiş bir ayrıcalık olmaktadır. Filistin bölgesi Yahudi geleneğinde de kutsal kabul edilmekle birlikte Halevi, dünyanın kalbi diye nitelendirdiği Filistin topraklarını emr-i ilâhî ile bağlantının ve dolayısıyla peygamberliğin gerçekleştiği yegâne bölge şeklinde sunmaktadır. ${ }^{106}$ Buna göre Filistin toprakları dışında da İsrâil Tanrısı'na ibadet etmek mümkündür; ancak emr-i ilâhî ile bağlantı sadece Filistin bölgesine ve İsrâil soyuna mahsustur.

Öte yandan Halevi'ye göre Tanrı'ya ulaşmak yani emr-i ilâhî ile bağlantı kurmak da ancak Tanrı'nın emrettiği amelleri yerine getirmekle mümkündür. Meleğin rüyasında krala, niyetinin sahih ama amellerinin yanlış olduğunu söylemesi bu sebebe dayanmaktadır. ${ }^{107}$ Sahih amellerin nelerden oluştuğunu bilmek için ise vahye ihtiyaç vardır. İsrâiloğulları'na özel olarak verilen ve İsrâil topraklarında yaşamayı gerektiren Tevrat kuralları, bir topluluğun devamı için asgari seviyede gerekli olan aklî kuralların üzerine ilâve olunmuş ve İsrâiloğulları'nın ilâhî emirle bağlantısını sağlayan kurallara karşılık gelmektedir. Diğer toplumlar genel tabiat kurallarına tâbi olurken (genel takdir) Yahudiler'in kaderi ise Tanrı'nın özel ve tabiat üstü takdirine bağlı olmaktadır. ${ }^{108}$ Bu noktayla bağlantılı olarak Halevi'nin, Yahudi dinine girmenin (erkekler için) ilk şartı olan sünnet uygulaması ile İslâm’ın ilk şartı

105 el-Kitâbü'l-Hazerî, 1:95.

106 “(...) Tipkı bu dağ dışındaki hiçbir dağa iyi bağ kurma (özelliği) bahşedilmediği gibi, emr-i ilâhî ile bağlantı halinde olma ayrıcalığı da bu yer (Şam/Filistin) dışındaki hiçbir yere bahşedilmemiştir” (el-Kitâbü’l-Hazerî, 2:12, 14). Halevi’ye göre İsrâil peygamberleri ya bizzat Filistin'de ya da Filistin bölgesiyle alâkalı olarak peygamberlik görevinde bulunmuşlardır (el-Kitâbü'l-Hazerî, 2:14, 16-20). Halevi, "peygamberlik mekânı” şeklinde adlandırdığı bu bölgeyi "Kızıldeniz (bahrü Sûf) ile Filistin denizinin (bahrü Filistîn) arasındaki, Sînâ çölünü, Fârân’, Seir’i ve Mısır’ da kapsayan bölge” şeklinde tanımlamaktadır (el-Kitâbüll-Hazerî, 4:3).

107 Halevi, söz konusu niyet-amel ilişkisini Hıristiyanlar’’n ve Müslümanlar’’n durumuna da uygulamaktadır. Hazar kralının filozofa karşı yaptığı açıklamada, bu iki dinî grubun doğruluk iddiasıyla birbirleriyle savaşmaları, hakikatin niyete değil amele bağlı olduğunun delili olarak sunulmaktadır: "Kral: (...) Ben ruh bakımından saf olduğumu, amellerimin de Rabb’in rızasına uygun olduğunu zaten biliyorum. Fakat aldığım cevap, bu amelin makbul olmadığı, ancak niyetimin makbul olduğu şeklinde. Bu durumda, kuşkusuz, niyete bağlı olmaksızın bizâtihi makbul olan bir amel olmalı. Öyle değilse, dünyayı bölüşen Hıristiyanlar ve Müslümanlar, her biri niyetini Allah’a halis kılarak, rahip ve zâhit olarak, oruç tutarak ve namaz kılarak birbiriyle (ne diye) savaşıyor ve bunun en büyük sevap olduğunu ve (kişiyi) Allah'a yakınlaştırdığını düşünerek, kararlı bir şekilde arkadaşını öldürüyor. Her bir (taraf) varacağı yerin cennet ve firdevs olduğuna inanarak savaşıyor. Halbuki her ikisinin birden doğru olduğunu kabul etmek mantığa aykırı” (el-Kitâbü’l-Hazerî, 1:2).

108 el-Kitâbül-Hazerî, 1:109; 2:44-50; 3:7. 
olan kelime-i şehadet arasında yaptığı mukayese ve sünnet ahdine yüklediği mâna bilhassa önemlidir: "Biz sadece tek bir kelimeyle dinimize giren herkesi kendimize eşit kabul etmeyiz; bilakis bu dindeki temizlik, (Tevrat) öğrenimi, sünnet olma ve daha birçok dinî amel türünden nefse zor gelen amelleri (yapmasını) ve bizim âdetlerimize göre hareket etmesini (isteriz). Sünnetin ilâhî bir işaret olduğunu, Allah’ın bunu aşırı şehveti bastırmak için (...yani) gerektiği yerde, gerektiği zamanda ve gerektiği şekilde döl vermek için kullanılsın diye ve (bu şekilde) emr-i ilâhîyi almaya uygun temiz bir döl oluşsun diye emrettiğini daima hatırlamak sünnetin şartlarından ve sebeplerindendir. Bu yoldan ayrılmayan kişi için ve soyu için ilâha yakın olma şeklinde güzel bir pay ayrılmıştır."109

Halevi'ye göre İsrâiloğulları için özel bir şeriatın takdir edilmesi bütün insanlar için de geçerli olan yaratılmış olmaları sebebiyle değil, Tanrı tarafından kendi has kavmi olmaları için Mısır'dan çıkarılmaları sebebiyledir. ${ }^{110}$ O sebeple Halevi'ye göre, sonradan Yahudi olanlar, soy olarak Yahudi olanlara denk olmamaktadır. ${ }^{11}$ Buna göre Yahudiler'in diğer topluluklardan farkı, zihnî veya ahlâkî açıdan ziyade dinî kabiliyet açısındandır. Bu kabiliyetin gelişmesi ve hayata geçirilmesi ise ilâhî yasaya yani Yahudi şeriatına bağlı olmaktadır. ${ }^{112} \mathrm{Bu}$ noktayla irtibatlı olarak Halevi, en yüksek dindarlığın zühtle değil, Tanrı̉nın iradesinin uygulaması olan dinî kurallara göre yaşamakla temin edilebileceğini ifade etmekte ve itidal konusu üzerinde durmaktadır. ${ }^{113}$ İtidale yönelik bu vurgu da ifrattan ve tefritten uzak yani orta yol ve denge üzere olmayı tavsiye eden İslâm anlayışının izlerini taşımaktadır.

Halevi’nin Yahudi pratiğine ve itidale paralel olarak işaret ettiği bir diğer husus Yahudi dininin vaatlerinin öncelikli olarak bu dünyaya yönelik olduğudur. Halevi'ye göre bütün diğer dinlerin (şerâit) vaatleri ölüm sonrası hayat1, kendi ifadesiyle "cennet bahçeleri ve güzel lezzetleri" içerirken Yahudi dininin vaatleri kutsal topraklarda, -tabii kanuna değil- doğrudan emr-i ilâhîye yani ilâhî iradeye bağlı olarak ve işledikleri amellere göre huzur ve bolluk içinde yaşamayı esas almaktadır. Burada da Halevi aslında Kur'an'daki cennet tasvirini eleştiri konusu yapmaktadır. Halevi'ye göre Yahudi vaadinin temelini oluşturan "emr-i ilâhî ile bağlantı"nın, diğer bir ifadeyle "Rabb’e ve meleklerine yakın olma” beklentisinin, öteki dünyadan önce bu dünyada

\footnotetext{
109 el-Kitâbül-Hazerî, 1:115.

110 el-Kitâbüll-Hazerî, 1:27.

111 el-Kitâbüll-Hazerî, 1:27.

112 Guttman, Philosophies of Judaism, s. 145, 147.

113 el-Kitâbüll-Hazerî, 2:50.
} 
gerçekleşen ve hatta gerçekleşmiş bir vaat olduğu anlaşılmaktadır. ${ }^{114} \mathrm{Bu}$ sebeple Halevi, hayattayken Allah'a yakın olan Yahudiler'in öldükten sonra elde edecekleri derecenin de bu yakınlık ilişkisine göre belirlendiğini ifade etmekte ve bu dereceye ulaşanlar için yok olma korkusunun bulunmadığını belirtmektedir. ${ }^{115}$ Bir başka yerde de dünya hayatı ve uzun yaşam ile âhireti kazanma arasında paralellik olduğuna işaret etmektedir: "(Âbit kişi) dünyayı ve uzun yaşamayı sever; bu ona âhireti kazandırır. Zira (bu dünyada) iyiliğini arttıran her şey âhirette de derecesini yükseltir."116 Halevi ayrıca âhiret bahsinin, Tevrat'ta ve peygamber kitaplarında fazla yer işgal etmese de Yahudi din âlimleri tarafından açık ve ayrıntılı biçimde tartışıldığını, sonraki dinlerin bu konuda yeni bir şey ortaya koymadığını ileri sürmektedir. ${ }^{117}$ Bütün bu açılamaların hem Kur'an'da sunulan âhiret anlayışına yönelik bir eleştiri hem de Yahudiler'in dünya hayatına düşkün oldukları şeklindeki Kur’an eleştirisine ${ }^{118}$ bir cevap teşkil ettiği anlaşılmaktadır.

Yahudiler'in içinde bulundukları düşük konum (zillet ve meskenet) ile ilgili olarak Halevi’nin ileri sürdüğü argüman ise diğer iki din mensuplarının da başlangıçta mâruz kaldıkları aşağılanma, baskı ve kıyımı doğru yolda olduklarının göstergesi olarak gördükleri ve bunu bir övünç vesilesi olarak sundukları şeklindedir. Halevi’ye göre, Yahudiler’in mevcut sürgün durumu kendi tercihleriyle ortaya çıkmış bir durum olmasa da bu duruma kendi istekleriyle katlanmaları, tek bir kelimeyi telaffuz ederek kolay yoldan yöneticilerinin dinine -yani İslâm’a- girmek ve kendilerini hor görenlerin gözünde makbul duruma gelmek varken Yahudi dinine sadık kalmak suretiyle zor

114 el-Kitâbü'l-Hazerî, 1:109. Bu bağlamda Halevi, Tevrat'ta İsrâiloğulları́na hitaben, “Sizden kim huzuruma gelir ve semaya yükselirse bizzat meleklerin arasında dolaşan şahıslar gibi olur; meleklerim de yeryüzünde onların arasında dolaşır” dendiğini belirtmektedir. Bu ifade âhiret hayatı çağrışımı yapıyor gibi görünse de söz konusu Tevrat cümlesiyle, öncelikli olarak Yâkub’un müşahede ettiği göğe dikilmiş merdiven ve bu merdivenden yeryüzüne inip çıkan meleklere yönelik Tekvin pasajının (28:1220) kastedildiği anlaşılmaktadır (bk. el-Kitâbül-Hazerî, s. 222, dn. 2; ayrıca bk. Çıkış 14:19-20; 23:20-23; Mezmurlar 91:11).

115 el-Kitâbüll-Hazerî, 1:111.

116 el-Kitâbül-Hazerî, 3:1.

117 el-Kitâbül-Hazerî, 1:115-17. Halevi'nin işaret ettiği, Tevrat'ta ve peygamber kitaplarında yer alan âhiretle alâkalı pasaj örnekleri şunlardır: Âdem’in içinde yaratıldığ Aden bahçesi ( gan Aden/cennet - Tekvin 2:8) ve Beytülmakdis'in yakınındaki ateşi son bulmayan çukur (gey ben-hinnom/cehennem - II. Krallar 23:10; Yeremya 7:31-32; 32:35); Samuel peygamber dönemindeki ölüye danışma uygulaması (I. Samuel 28:519); Tevrat'ta yer alan, yabancı bir peygamberin ölümle ilgili duası (Sayılar 23:10); ayrıca Yahudi sabah duasında yer alan âhirete, ruha ve yeniden dirilmeye yönelik ifade.

118 Bk. el-Bakara 2/96. 
yolu seçmeleri, Tanrı̉yla olan ilişkilerinin yakınlığının bir sonucu ve aynı zamanda kurtuluşu yakınlaştıran bir unsur olmaktadır. ${ }^{19}$ Yine bu açılamanın da hem Hıristiyanlar’n hem de Müslümanlar’n tezlerine karşı bir cevap niteliğinde olduğu anlaşılmaktadır.

Halevi'ye göre Yahudiler'in mâruz kaldıkları sürgün durumu, temelde onların hatalarının bir sonucu olsa da, bu sürgünün özel bir tarafı söz konusudur. Bu noktada Halevi, İsrâil'in yani Yahudiler'in milletler içindeki konumunu, "kalbin bütün diğer organlar içindeki konumu"na benzetmekte ve tıpkı diğer organlarda ortaya çıkan sıkıntıların doğrudan kalbi etkilemesinde olduğu gibi, Yahudiler'in hem kendi hatalarından hem de dolaylı olarak diğer milletlerin hatalarından dolayı hastalıklı hale geldiklerini ileri sürmektedir: "Emr-i ilâhînin bizimle ilişkisi, nefsin kalple ilişkisi mertebesindedir. Onun için 'Yerin bütün aileleri içinde sadece sizi bildim. O yüzden bütün günahlarınız için sizi cezalandıracağım'120 denmiştir." ${ }^{121}$ Fakat, Halevi'ye göre, Yahudiler'in içinde bulundukları sürgün durumu, onları "kuru kemikler"den ${ }^{122}$ ibaret olan "dağılmış uzuvlar" haline getirmiş olsa da, "bir zamanlar bir kalbin, başın, ruhun, nefsin ve aklın taşıyıcısı olan bu kemikler" yani en zelil haliyle bile Yahudiler, "mermerden ve alçıdan yapılmış, başları, gözleri, kulakları ve bütün âzaları bulunan fakat içine hayat ruhu hiç girmemiş ve girmesi de mümkün olmayan cesetlerden" yani en parlak haliyle bile diğer milletlerden daha üstün konumda bulunmaktadır. ${ }^{123}$

Öte yandan Halevi'nin seçilmiş soy ve seçilmiş toprak görüşünün de Yahudi geleneğinin ötesinde ${ }^{124}$ Şiî-İsmâilî literatürden, bilhassa Şî̀ imam doktrini ve seçkin soy modelinden beslendiğine yönelik yorumlar yapılmıştır. Bu noktada bilhassa Shlomo Pines ve Ehud Krinis, X. yüzyılda yaşamış Zeydî âlim Kāsım b. İbrâhim, Şiî-İsmâilî âlim Ca'fer b. Mansûr el-Yemen ve Ebû Ya'kūb es-Sicistânînin eserleri ile İhvân-1 Safâ risâlelerinde, bilhassa er-Risâletü'l-câmia adlı metinde yer alan benzer görüşlere atıf yapmışlardır. Bu görüşlerin başında, Kuzari’deki kullanımdan bazı farklılıklar içerse de, Ehlibeyt soyundan gelen imam silsilesiyle bağlantılı olarak ilâhî seçim mânasındaki safvet kelimesinin, yine Halevi’nin düşüncesinde önemli yere sahip olan ilâhî emir/takdir ve ilâhî seçim mânasındaki emrullah ve

119 el-Kitâbül-Hazerî, 1:112-15.

120 Amos 3:2.

121 el-Kitâbül-Hazerî, 2:36-44.

122 Hezekiel 37:3.

123 el-Kitâbül-Hazerî, 2:31.

124 Halevỉnin seçilmiş soyla ilgili görüşlerinin Rabbânî gelenekteki dayanağıyla ilgili olarak bk. Lasker, "Proselyte Judaism, Christianity, and Islam”, s. 75-92. 
ihtiyârullah ifadelerinin kullanılması, ilâhî emrin Âdem ile başlatılması ve daha sonra Âdem'in çocukları içinden seçkin/saf olanlara yani peygamberlere intikalinden bahsedilmesi, dinin ve İslâm’ın kemalinin Allahı̉n seçkinlerine ait olduğunun söylenmesi gibi görüşler gelmektedir. ${ }^{125}$ Ayrıca İhvân-1 Safầya ait bir risâlede, Halevỉnin görüşlerine ve zikrettiği varlık kategorisine ilham teşkil edecek şekilde, Irak (veya İran) halkıyla ilgili olarak şu açıklamanın yapıldığına dikkat çekilmiştir: "Biz, insanlığın kalbi (lübbü̈n-nâs), insanlık hayvanatın kalbi; hayvanat nebatatın kalbi; nebatat minerallerin kalbi; mineraller de elementlerin kalbidir." Buna ilâveten Irak halkının peygamberlik lütfuna mazhar olmasından ve Irak topraklarının diğer topraklar arasında merkezî konumda bulunmasından da bahsedilmiştir. ${ }^{126}$

Pines'a göre Halevi, Şî̀ literatürde yer alan bütün bu kavramları ve görüşleri Yahudiliğe uyarlamak suretiyle kendi teorisini ortaya koymuştur. $\mathrm{Bu}$ noktada, tersinden bir mantıkla sorulması gereken soru, Halevi'den önce yaşamış olan söz konusu Şiî yazarların da Yahudi geleneğinde zaten var olan seçilmiş soy ve seçilmiş toprak fikrinden etkilenip etkilenmedikleridir. Pers geleneğinin Yahudilik'le ilişkisi Bâbil sürgünü dönüşüyle birlikte başlayan Yahudi-Pers münasebetine ve daha sonra Talmud dönemindeki YahudiSâsânî ilişkisine kadar uzanmaktadır. Şiî İslâmı̉nın arka planında Pers geleneğinin de yer alması söz konusu etkiyi mümkün kılmaktadır. ${ }^{127}$

\section{3. İslâm Eleştirisinin Temeli Olarak Evrensellik İddiası}

Halevi’nin Kuzari'de ortaya koyduğu Yahudilik savunusunun diğer ayağını oluşturan İslâm’a yönelik eleştiri, en başta işaret edildiği üzere, Yahudi seçilmişlik inancının bir nevi antitezi konumundaki evrensellik iddiası üzerine temellenmektedir. Yukarıdaki bölümlerde bir kısmına işaret edilen diğer eleştiriler de umumiyetle bu noktayla bağlantılı olarak ortaya konmaktadır. Bu mânada Halevi’nin İslâm’a yönelik birincil eleştirisi, İslâm mesajının sadece belli bir kavimle sınırlı kalmayıp bütün insanlığı hedefliyor olmasıdır. Halevi'ye göre Mûsâ peygamber ile İslâm peygamberinin mesajları

125 Pines, "Shī'ite Terms and Conceptions in Halevi's Kuzari”, s. 167-72; Krinis, "The Arabic Background of the Kuzari”, s. 24-36; ayrica bk. Rubin, "Prophets and Progenitors in Early Shīa Tradition", s. 41-65.

126 Bk. Pines, "Shīite Terms and Conceptions in Halevi’s Kuzari”, s. 189-90, dn. 168b; Lobel, Between Mysticism and Philosophy, s. 38.

$127 \mathrm{Bu}$ noktayla bağlantılı olarak çeşitli Yahudi yazarlar Yahudi geleneğinin, hem inanç hem de uygulama noktasında, Şiî̀ İslâmı üzerindeki etkisine dair Sünnî gelenek içinde var olan kanaate dikkat çekmişlerdir. Meselâ bk. Wasserstrom, Between Muslim and Jew, s. 93-135 ("Shi'ite and Jew Between History and Myth" başlıklı bölüm). 
arasındaki temel fark da buraya dayanmaktadır. Mûsâ, kölelikten kurtulmak ve Kenan topraklarına girmek şeklindeki, gerçekleştirilebilir ve netice itibariyle gerçekleştirilmiş bir vaatle İsrâiloğulları̉na gelmiştir. Halevỉnin ifadesiyle bu durum, elçiyi "gönderenin büyüklüğ̈nün, elçinin yüceliğinin ve özel olarak kendilerine elçi gönderilenlerin faziletinin ispatı" olmaktadır. Buna karşıllk Halevi İslâm Peygamberi’nin, "Ben bütün dünyayı doğru yola sevketmek için gönderildim” diyerek geldiğini ("âlemlere rahmet olarak gönderilme" sözüne atıf), fakat mesajının dünyanın sadece bir yarısına ulaşmış ve amaçlanan hedefin gerçekleşmemiş olduğunu ima etmektedir. Böyle bir peygamber, Halevi'nin ifadesiyle, "elçiliğinde itibarsız duruma düşmüş" olmaktadır. ${ }^{128}$ Dolayısıyla Kuzari'de ortaya konduğu şekliyle Yahudi anlayışında peygamberliğin/seçilmişliğin ve ilgili mesajın İsrâiloğulları ile sınırlı olması Halevi tarafından bir eksiklik olarak görülmemekte; aksine, İslâm ile ilişkilendirdiği, evrensel olma iddiasıyla yola çıkıp bunu başaramamak bir eksiklik kabul edilmektedir.

Halevi'ye göre diğer milletleri de hedefleyen İslâm mesajının önündeki en büyük engel ise Kur'an’nn Araplar’ın lisanında gelmiş olmasıdır. Bu durum Kur'an’n Arap olmayan Müslümanlar tarafından anlaşılmasını zorlaştırmaktadır. ${ }^{129} \mathrm{Bu}$ sebeple, Halevi'nin ifadesiyle, Arap olmayan milletlerin bu "kitapla amel etmeleri ancak seneler geçtikten sonra, fetihler veya komşuluk yoluyla onlarda dönüşümün gerçekleşmesiyle" meydana gelmektedir; Yahudi dininde olduğu gibi, "peygamberin bizzat şahitlik etmesiyle ya da başka bir peygamberin o (peygamber)e şahitlik edip onun şeriatını desteklemesiyle değil." ${ }^{130}$ Halevi, bu şekilde, temel olarak belli bir topluluğu (İsrâiloğullar1/ Yahudiler) muhatap alan Yahudi dininin, bu topluluğun ana dili olan İbrânîce gelmiş olmasının ve yine aynı dili konuşan her bir peygamberin mesajlarıyla bu kitabı ve dini teyit etmelerinin bir üstünlük unsuru olduğuna işaret etmektedir.

Halevi, Arapça bir metin olarak Kur'an’ın îcazı konusunu da bir problem olarak ortaya koymaktadır. Bu noktada Halevi’nin Hazar kralının ağzından dile getirdiği eleştiri son derece ilginçtir: "Her kim hidayetini emr-i ilâhîde ararsa ve bunun imkânsız olduğunu düşündüğü halde Allah’̉n beşerle konuştuğuna kanaat getirirse, bu kanaate redde mahal vermeyecek şekilde bilinen gerçekler yoluyla varmış olması gerekir ki ancak o zaman Allahı̉n beşerle konuşmuş olduğuna inanabilsin. Kitabınız, Arapça yazılmış bir kitap (olarak) mûcize olabilir, (ama) benim gibi Arap olmayan biri onun mûcize ve

128 el-Kitâbül-Hazerî, 1:100.

129 el-Kitâbüll-Hazerî, 1:6; krş. 3:67.

130 el-Kitâbül-Hazerî, 1:100. 
hârikulâde oluşunu anlayamaz, (dolayısıyla) bana (kitabınız) okunduğunda ben onunla başka bir Arapça kelâm arasındaki farkı ayırt edemem."131

Halevinnin İslâm'a yönelik bir diğer eleştiri noktası ise bu dine girmenin, kendi ifadesiyle, sadece bir kelimeyi yani kelime-i şehadeti telaffuz etmekle gerçekleşmesidir. Halevi'ye göre bu kişi "belki de ömrü boyunca bu kelimeden başka bir şey bilmemiş ve hatta bu kelimenin mânasını dahi anlamamış olsa bile, naîm (cennetlerin)de sonsuza kadar yaşamaktadır. Tek bir kelime (kişiyi) hayvan derecesinden (alıp) yüce meleklerin derecesine yükseltmektedir. Bu kelimeyi telaffuz etmeyen kişi ise bütün hayatı boyunca Allah Teâlâya ulaşmak için çabalamış âlim ve âbit bir filozof olsa bile bir hayvan (derecesinde) kalmaktadır." ${ }^{132}$ Halevi'ye göre Yahudi dininde ise durum farklıdır: "Biz, hangi ümmetten olursa olsun (hiç)bir kimseyi Allah katında faziletin karşıllğıından mahrum etmeyiz. Fakat tam fazileti hayattayken (Allah’a) yakınlaştırılmış olanlara ait görürüz. Onların öldükten sonra Allah katındaki derecelerinin de bu (yakınlık) ilişkisine uygun olduğunu kabul ederiz." 133

Halevinnin ortaya koyduğu bu hususlarla ilgili olarak şunları söylemek mümkündür: Her şeyden önce, Halevi’nin, mesaj-başarı ilişkisi ya da denklemi üzerinden yaptığı Yahudilik-İslâm karşılaştırması sorunlu bir bakış açısı sunmaktadır. Halevi’nin iddiasının aksine İslâm mesajının sadece belli bir grubu değil, bütün insanlığı hedefliyor olması, tek tek bütün fertleri ya da insanlığın tamamını Müslüman yapma gibi bir iddia taşımamaktadır. Böyle bir şeyin imkânsız olduğu bizzat Kur'an tarafından ifade edilmektedir. Kur'an'da yaratılış kıssası üzerinden, insanoğlundan bir kısmının ve belki de çoğunun doğru yoldan çıkacakları ya da yanlış yolda olacakları ihtimalinin daha en başından Tanrı̉nın bilgisi ve takdiri dahilinde olduğu bildirilmekte ve yine çeşitli âyetlerde Peygamber'e, inanmayanlar karşısında üzüntüye kapılmaması için telkinde bulunulmaktadır. ${ }^{134}$ Dolayısıyla İslâm Peygamberi adına "âlemlere rahmet olma" vurgusunun ifade ettiği evrensellik iddiası, sayı çokluğundan ziyade son peygamberin tebliğinin bütün zaman ve mekânlara hitap edecek şekilde kemale erdirilmiş ve tamamlanmış bir din (şeriat) olma vasfı taşıdığını, artık yeni bir peygamberin ve yeni bir dinin gelmeyeceğini ifade etmektedir.

131 el-Kitâbül-Hazerî, 1:6.

132 el-Kitâbül-Hazerî, 1:110, 4:23.

133 el-Kitâbül-Hazerî, 1:111.

134 Bk. en-Nisâ, 4/119; el-A'râf, 7/16-18; Âl-i İmrân, 3/176; en-Nahl, 16/32; el-Gāşiye, 88/21-22. 
Yine Kur’an’n îcazı ile ilgili argümandaki problemli husus, Halevỉnin, mûcize olma bakımından bir metnin karşısına tarihî bir hadiseyi yerleştirmesidir. Halevi’nin yürüttüğü bu mantığ 1 kabul edecek olursak, Kur’an’nn mûcize oluşunu ve dolayısıyla vahiy eseri olduğunu en iyi Araplar’n, daha doğrusu Arapça’yı bilenlerin anlaması ile Tanrı’nın beșerle konuştuğunu en iyi Sînâ vahyini tecrübe edenlerin anlaması arasında bir fark olmamalıdır. Fertler arası anlayış farklılığ 1 ise her iki durum için de geçerlidir. Öte yandan Arap olmayanlar ya da Arapça bilmeyenler ile Sînâ vahyini doğrudan tecrübe etmeyenler arasında bir mukayeseye gidildiğinde ise durum farkl1laşacaktır. Arap olmayan birinin (meselâ bir Yahudi’nin) Arapçảyı bir Arap kadar hatta ondan daha iyi öğrenmesi ve Arap olan Müslümanlar'ın şehadetine ve aktardığı bilgiye bağlı kalmadan bizzat kendisinin, elinin altında bulunan Kur’an metni (yani bu metnin üslûbu, içeriği, îcazı vb.) hakkında hüküm vermesi mümkündür ve bunun örnekleri İslâm tarihinde mevcuttur. Arapça'yı bilmeyenler ise bu konuda Halevi’nin çok kıymet verdiği bir kavram olan taklide yani kendi geleneklerinin şehadetine başvuracaklardır. Buna karşılık Sînẩda bulunmayanların geriye dönük olarak bu olayı yaşamaları ve önceki nesillerin şehadeti olmaksızın bu olay hakkında doğrudan fikir sahibi olmaları mümkün değildir. Bu mânada Sînâdaki vahyi tecrübe etmeyen kişi için Sînẩda yaşanan mucizeler ile meselâ havârilerin Îsâ Mesih üzerinden tecrübe ettiği mûcizeler arasında inandırıcılık açısından bir fark yoktur. Dolayısıyla aslında Halevi’nin mantığına göre, bir hikâyenin ya da haberin bilindik olması yani Mûsẩnın sergilediği mûcizelerin İnciller'de ve Kur'an'da da yer almış olması, bu hikâyenin yanlıs veya hayalî olamayacağı anlamına gelmemektedir. Bunun tersini söylemekle aslında Halevi kendisiyle çelişmektedir. ${ }^{135}$ Zira eğer durum Halevi'nin söylediği gibi ise Halevi’nin aynı şekilde hem İnciller'in hem de Kur'an’ın Îsâ Mesih’e atfettiği mûcizeleri de kabul etmesi gerekirdi. ${ }^{136}$ Dolayısıyla Halevỉnin iddiasının aksine, metin olarak mevcudiyetini koruyan Kur'an’n mûcize olma ve her devrin insanı için (Müslüman veya değil) ulaşılır olma vasfı, geçmişte yaşanmış ve sadece

135 “(Müslüman) âlim şöyle dedi: Kitabımız Mûsâ’nın (as) ve İsrâiloğulları’nın haberleriyle dolu değil mi? Onun firavuna yaptıkları, denizi yardığı ve kendinden razı olduklarını kurtarıp kızdıklarını da boğduğu inkâr edilemez. Ayrıca kırk yıl boyunca (gönderdiği) men ve selva, Tûr'da Mûsâ ile konuşması, Yeşu için güneşi durdurması ve güçlü kuvvetli (adam)lar karşısında ona yardım etmesi var. Bundan öncesinde de tûfan ve Lût kavminin helâk edilmesi var. (Bütün) bunlar hayale ya da hileye yer bırakmayacak kadar bilindik (hadiseler) değil mi?" (el-Kitâbül-Hazerî, 1:9).

136 Burada ileri sürdügümüz eleştirilere benzer eleştiriler Semevel el-Mağribînnin reddiyesinde de, İslâm’ın ve Hz. Muhammed'in nübüvvetinin ispatı bahsinde dile getirilmektedir. Arapça metin için bk. İfhâmül-Yehûd, s. 12-15; Türkçe tercümesi için ayrıca bk. Yahudiliği Anlamak, s. 47-53. 
belli bir topluluk tarafından tecrübe edilmiş bir hadiseye karşılık gelen Sînâ vahyinin mûcize olma vasfından daha üstün konuma sahiptir. ${ }^{137}$ Belki de onun için, Halevi’nin çok sevdiği tabiri kullanacak olursak, emr-i ilâhînin bir sonucu olarak, daha dar bir topluluğu hedefleyen $\mathrm{Hz}$. Mûsẩnın tebliğinde zaman ve mekânla sınırlı mûcizeler (Mısır ve Sînâ mûcizeleri), evrensellik iddiası taşıyan Hz. Muhammed'in tebliğinde ise zaman ve mekân üstü bir mûcize (Kur'an metni) takdir edilmiş olmaktadır. Fakat Halevi’nin kurgusuna göre, dil engeli sebebiyle Arapça Kur'an’n mûcize oluşunu kavrayamayacağını söyleyen Hazar kralı, tecrübe etmediği halde Sînâ vahyinin gücü sebebiyle Yahudiliği benimsemekte ve aynı dil engeline rağmen İbrânîce Tevrat'ın kutsallığını kabul etmektedir. Ayrıca Halevi, Arapça adına eleştiri konusu yaptığı üstünlük iddiasını bizzat kendisi İbrânîce için dile getirmektedir. ${ }^{138}$

Öte yandan Halevỉnin ileri sürdügü, kutsal metnin dili ve mesajın anlaşılırlığıyla ilgili argümanda da problem mevcuttur. Tanah’ta anlatıldığ 1 üzere, Bâbil sürgünü sırasında Yehuda'da kalan halk, ana dilleri olan İbrânîce'yi unutmuş ve kutsal metinleri olan Tevrat'in dilini anlayamayacak duruma gelmişlerdir. Sonraki büyük sürgün döneminde de farklı coğrafyalarda yaşamaya başlayan Yahudiler için İbrânîce ana dili olma vasfını yitirmiştir. Aynı şekilde İsrâiloğulları İbrânîce konuşmaya devam ettikleri ve bu dili konuşan peygamberlere sahip oldukları önceki dönemlerde de kitaplarıla amel etmeyi bırakmış ve putlara tapmaya başlamışlardır. Bu durum kutsal metnin ilk muhatabı ve taşıyıcısı olan grup hariç, kutsal metnin dili ile mesajın yayılması ve özümsenmesi arasında doğrudan bir bağ bulunmadığını göstermektedir. Ayrıca Tanah'ta yer alan bu bilgilere göre, Halevi’nin Arap olmayan Müslümanlar için yaptığı, onların, "Kitapla amel etmeleri ancak seneler geçtikten sonra, fetihler veya komşuluk yoluyla onlarda dönüşümün gerçekleşmesiyle meydana gelmektedir" şeklindeki tespite benzer bir durum İsrâiloğulları için de geçerlidir. Tanah’n şahitliğini kabul edecek olursak, Halevỉnin söylediğinin aksine Yahudi dini, "peygamberin bizzat şahitlik etmesiyle ya da başka bir peygamberin o (peygamber)e şahitlik edip onun şeriatını desteklemesiyle" tam anlamılla tesis edilmiş değildir; bilakis söz konusu şahitliğe ve

137 Kur'an ile Tevrat arasında bir mukayese yapıldığında ise tevâtür yoluyla sonraki nesillere aktarılmış olmaları ya da bu yöndeki iddia bakımından bu iki metin arasında teoride bir fark yoktur. Fakat derlenme süreçleri, mevcut nüshaların eskiliği ve otantiklik dereceleri bakımından iki metin arasında önemli farklar mevcuttur. Bu mukayese bu makalenin konusu olmadığından bu kadarına işaret etmek yeterli olacaktır. Konuya yönelik geniş bilgi için bk. A'zamî, Vahyedilişinden Derlenişine Kur'ân Tarihi; Adam, Yahudi Kaynaklarına Göre Tevrat.

138 el-Kitâbü'l-Hazerî, 2:67-68; ayrıca bk. Katzew, "Moses Ibn Ezra and Judah Halevi”, s. 191-92. 
desteğe rağmen bu din İsrâiloğulları̉nın hayatında uzun süre pratik olarak karşıllı bulmamıştır. Bu neticenin gerçekleşmesi için İsrâiloğulları’ndan arta kalanların Bâbil sürgünü tecrübesini yaşamaları ve sürgünden dönüşte Ezra önderliğinde yeni bir ahit yapmaları gerekmiştir. ${ }^{139}$

Yukarıda belirtilen bütün bu hususların Halevi tarafından göz ardı edildiği görülmektedir. Halevi, Kuzarissinde daha ziyade İslâm’nn temel karakteri (evrensellik) ile belli inanç ve uygulamalarını karikatürize edilmiş bir biçimde sunmakta; bu İslâm tasvirinin karşısına ise fazlasıyla idealize edilmiş ve monolitik bir Yahudilik tasviri yerleştirmektedir. Halevi'nin Kuzaride ortaya koyduğu hakikat ve Yahudilik tanımı çerçevesinde Yahudi dininin, hakikati en iyi temsil eden din olduğundan değil, belki en fazla, teorik anlamda, Halevi'nin koyduğu hedefler ya da sınırlar açısından iç tutarlılığa sahip bir din olduğundan bahsetmek mümkündür. Kuzarinnin sonraki Yahudi yazarlar üzerinde oluşturduğu etkiye rağmen, Halevi’nin sunduğu bu dar çerçeveli Yahudilik anlayışının, Yahudiliği evrensel açılıma sahip bir din olarak gören Yahudi yazarlara ne kadar açılım sağladığı ya da sağlayamadığı ise ayrı bir tartışma konusudur.

\section{Sonuç Yerine}

Belki en başta söylenmesi gereken şeyi şimdi söyleyecek olursak, kurgusallığı ve sunduğu argümanlar bakımından tenkide açık noktaları bir yana, Halevi’nin Kuzarisinin en önemli özelliği, müellifinin Yahudi, Müslüman ve Hıristiyan dünyasının kesiştiği bir coğrafyada ve dönemde yaşamış olması ve bu kesişimin izlerini, bilerek ya da bilmeyerek eserinde iyi bir şekilde yansıtmasıdır. Bu özelliğe paralel olarak, Kuzari aynı zamanda İslâm’ın Yahudi düşüncesi üzerindeki çok yönlü etkisinin sadece İbn Meymûn ve İbn Dâvûd gibi rasyonalist Yahudi âlimleri değil, aynı zamanda Halevi gibi gelenekçi Yahudi âlimleri kapsadığının da iyi bir örneğini oluşturmaktadır.

$\mathrm{Bu}$ makalenin amacı, Halevi’nin beslendiği kaynaklar, özellikle de arka plandaki Müslüman etkisi üzerine Yahudi araştırmacılar tarafından yapılıııs çalışmaları da dikkate alarak, Halevi’nin Kuzari’sindeki Yahudilik savunusunu ve buna paralel olarak dillendirdiği İslâm eleştirisini temel noktalar üzerinden değerlendirmekti. Kanaatimce bu makalede ortaya konan genel çerçeve, Türkçe'de fazla çalışılmamış olan Halevi gibi bir şahsiyetin hangi noktalar üzerinden çalışılabileceğine ve aynı zamanda burada temas edilen konuların her birinin de müstakil olarak çalışılmayı gerektirecek hacim ve

139 Bk. Gürkan, Yahudilik, s. 152-55. 
önemde olduğuna işaret eder özelliktedir. Bu bağlamda, İbn Meymûn'dan sonra Yahudi geleneğindeki en etkili isimlerden biri olan Halevi’nin gerek dinî-millî içerikli şiirlerinin gerekse Kuzari'deki görüşlerinin modern Yahudi düşüncesini nasıl etkilediği konusu bilhassa günümüz Yahudiliği’ni anlamaya ışık tutacak öneme sahiptir ve yeni çalışmalara davetiye sunmaktadır.

\section{Bibliyografya}

Adam, Baki, Yahudi Kaynaklarına Göre Tevrat, İstanbul: Pınar Yayınları, 2002.

A'zamî, M. Mustafa, Vahyedilişinden Derlenişine Kur'ân Tarihi: Eski ve Yeni Ahit ile Karşılaştırmalı Bir Araştırma, çev. Ömer Türker - Fatih Serenli, İstanbul: İz Yayıncılık, 2006.

Baron, Salo W., "Yehudah Halevi: An Answer to an Historic Challenge”, Jewish Social Studies, 3/3 (1941): 243-72.

Baer, Yitzhak, A History of the Jews in Christian Spain, çev. Louis Schoffman, I-II, Skokie: Varda Books, 5761/2001.

Baneth, David Hartwig, "Judah Halevi and al-Ghazali", çev. G. Hirschler, Studies in Jewish Thought: An Anthology of German Jewish Scholarship, ed. Alfred Jospe, Detroit: Wayne State University Press, 1981, s. 181-99.

Baneth, David Hartwig, "Some Remarks on the Autographs of Yehudah Hallevi and the Genesis of the Kuzari”, Tarbiz, 26 (1957): 297-303 [İbrânîce].

Beinart, Haim, “Toledo”, Encyclopaedia Judaica (EJd.), 2. ed., I-XXII, Detroit 2007, XX, 23-26.

Berger, Michael S., "Toward a New Understanding of Judah Halevi’s 'Kuzari”, The Journal of Religion, 72/2 (1992): 210-28.

Birnbaum, Ruth, "Judah Halevi and Martin Buber on the Radicalization of Judaism", Judaism, 34/4 (1985): 391-400.

Bodoff, Lippman, “Was Yehudah Halevi Racist?”, Judaism, 38/2 (1989): 174-84.

Brann, Ross, "Judah Halevi”, The Literature of Al-Andalus, ed. Maria Rosa Menocal v.dğr., Cambridge: Cambridge University Press, 2000, s. 265-81.

Brann, Ross, “Judah Halevi: The Compunctious Poet”, Prooftexts, 7 (1987): 123-43.

Brook, Kevin Alan, The Jews of Khazaria, 3. ed., New York: Rowman \& Littlefield Publishers, 2018; Türkçe'si: Hazar Yahudileri: Bir Türk İmparatorluğu, çev. İsmail Tulçalı, İstanbul: Nokta Kitap, 2005.

Cohen, Richard A., "Rosenzweig's Rebbe Halevi: From the Academy to the Yeshiva”, Judaism, 44 (1995): 448-66.

Cohon, Samuel S., "Jehuda Halevi”, The American Jewish Year Book, 43 (1941-42/5702): 447-88.

Dover, Cedric, “The Racial Philosophy of Jehuda Halevi”, Phylon, 13/4 (1952): 312-22.

Dunlop, D. M., The History of the Jewish Khazars, New York: Schocken Books, 1967. 
Efros, Israel, "Some Aspects of Yehudah Halevi's Mysticism", Proceedings of the American Academy for Jewish Research, 11 (1941): 27-41.

Epstein, Isidore, “Judah Halevi as Philosopher”, The Jewish Quarterly Review, 25/3 (1935): 201-25.

Feyyûmî, Saîd b. Yûsuf, el-Emânât ve’l-i'tikādât, nşr. S. Landauer, Leiden: Brill, 1880.

Fontaine, Resianne, “Was Maimonides an Epigone?", Studia Rosenthaliana, Epigonism and the dynamic of Jewish culture, 40 (2007-2008): 9-26.

Fontaine, Resianne, “Ibn Daud, Abraham ben David Halevi”, EJd., IX, 662-65.

Frank, R. M., "Al-Ghazālī on Taqlīd: Scholars, Theologians, and Philosophers", Zeitschrift für Geschichte der Arabisch-Islamischen Wissenschaften, 7 (1991-92): 207-52.

Friedman, Mordechai A., “Judah Ha-Levi on Writing the Kuzari: Responding to a Heretic", From a Sacred Source: Genizah Studies in Honour of Professor Stefan C. Reif, ed. B. M. Outhwaite - S. Bhayro, Leiden: Brill, 2011, I, 158-69.

Gazzâlî, Tehâfütü’l-felâsife, nşr. Süleyman Dünyâ, 6. bs., Kahire: Dârü’l-maârif, 1392/1972.

Goitein, Shelomo Dov, “The Biography of Rabbi Judah Ha-Levi in the Light of the Cairo Geniza Documents", Proceedings of the American Academy for Jewish Research, 28 (1959): 41-56.

Goitein, Shelomo Dov, “Autographs of Yehuda Hallevi”, Tarbiz, 25 (1955-56): 393-412 [İbrânîce].

Goitein, Shelomo Dov, A Mediterranean Society: The Jewish Communities of the Arab World as Portrayed in the Documents of the Cairo Geniza V: The Individual, Berkeley: University of California Press, 1988.

Guttman, Julius, Philosophies of Judaism: The History of Jewish Philosophy from Biblical Times to Franz Rosenzweig, New York: Anchor Books, 1966.

Gürkan, Salime Leyla, Yahudilik, 5. bs., İstanbul: İSAM, 2015.

Halevi, Yehuda, Sefer Ha-Kuzari: Makor ve-Targum, çev. Yosef Kafih [Kafah], Kiryat Ono: Makhon Mishnat Ha-Rambam, 5765/2005.

[Halevi] Lâvî, Ebü'l-Hasan Yehûdâ b. Semev’el, el-Kitâbü'l-Hazerî: er-Red ve'd-delîl fiddîni'z-zelîl, nşr. Nebîh Beşîr, Beyrut/Köln: Menşûratü’l-cemel, 2012.

Halkin, Hillel, Yehuda Halevi, New York: Schocken, 2010.

Halper, Yehuda, ed., Philosophy and the Jewish Tradition: Lectures and Essays by Aryeh Leo Motzkin, Leiden: Brill, 2012.

Heinemann, Isaac, ed., "Judah Halevi: Kuzari”, Three Jewish Philosophers, ed. Hans Lewy v.dğr., Cleveland: Meridian Books, 1960.

Hellig, Jocelyn, “The Jewish Golden Age of Spain Revisited", Religion in Southern Africa, 3/2 (1982): 23-33.

Hirschfeld, Hartwig, "Introduction", Judah Hallevi's Kitab Al Khazari, çev. Hartwig Hirschfeld, London: George Routledge and Sons Ltd., 1905, s. 1-35.

Hughes, Aaron W., “The Art of Philosophy: The Use of Dialogue in Halevi's Kuzari and Abravanel's Dialoghi d'Amore", Medieval Encounters, 13 (2007): 470-98.

Husik, Isaac, A History of Medieval Jewish Philosophy, New York: Atheneum, 1969. 
Irmak, Adem, "Yehuda Halevi ve Ahiret Düşüncesi", Bülent Ecevit Üniversitesi İlahiyat Fakültesi Dergisi, 2/2 (2015): 301-18.

İbn Meymûn, Delâletü'l-hâirîn, nşr. Hüseyin Atay, Kahire: Mektebetü's-sekāfeti'd-dîniyye, t.y.

The Itenerary of Rabbi Benjamin of Tudela, çev. ve ed. A. Asher, I-II, London-Berlin: A. Asher \& Co., 1840-41.

Judah Hallevi's Kitab Al Khazari, çev. Hartwig Hirschfeld, London: George Routledge and Sons Ltd., 1905.

Kaplan, Lawrence, “'The Starling's Caw': Judah Halevi as Philosopher, Poet and Pilgrim”, The Jewish Quarterly Review, 101/1 (2011): 97-132.

Katzew, Jan D., "Moses Ibn Ezra and Judah Halevi: Their Philosophies in Response to Exile”, Hebrew Union College Annual, 55 (1984): 179-95.

Kfir, Uriah, A Matter of Geography: A New Perspective on Medieval Hebrew Poetry, Leiden: Brill, 2018.

Kogan, Barry S., "Judah Halevi”, History of Islamic Philosophy, ed. Seyyed Hossein Nasr Oliver Leaman, New York: Routledge, 1996, s. 718-724; Türkçesi: “Judah Halevî”, İslâm Felsefesi Tarihi, çev. Şamil Öçal - Hasan Tuncay Başoğlu, İstanbul: Açllım Kitap, 2007, s. 395-402.

Kogan, Barry S., "Judah Halevi and His Use of Philosophy in the Kuzari", The Cambridge Companion to Medieval Jewish Philosophy, ed. Daniel H. Frank - Oliver Leaman, Cambridge: Cambridge University Press, 2003, s. 111-35.

Kogan, Barry S., "Al-Ghazali and Halevi on Philosophy and the Philosophers", Medieval Philosophy and the Classical Tradition: In Islam, Judaism and Christianity, ed. John Inglis, London-New York: Routledge Curzon, 2002, s. 54-68.

Kreisel, Howard, "Judah Halevi's Influence on Maimonides: A Preliminary Appraisal", Maimonidean Studies, 2 (1991): 95-121.

Kreisel, Howard, Prophecy: The History of an Idea in Medieval Jewish Philosophy, Kluwer Academic Publishers, 2001.

Krinis, Ehud, “The Arabic Background of the Kuzari”, Journal of Jewish Thought and Philosophy, 27 (2013): 1-56.

The Kuzari: In Defense of the Despised Faith, 2. ed., çev. N. Daniel Korobkin, Jerusalem: Feldheim, 2009.

Kuzgun, Şaban, Hazar ve Karay Türkleri: Türklerde Yahûdilik ve Doğu Avrupa Yahûdilerinin Menşei Meselesi, Ankara: Se-da Yayınları, 1985.

Langermann, Y. Tzvi, “Science and the Kuzari”, Science in Context, 10/3 (1997): 495-522.

Lasker, Daniel J., "Proselyte Judaism, Christianity, and Islam in the Thought of Judah Halevi”, The Jewish Quarterly Review, 81/1-2 (1990): 75-91.

Lasker, Daniel J., "Judah Halevi and Karaism”, From Ancient Israel to Modern Judaism: Intellect in Quest of Understanding, Essays in Honour of Marvin Fox, ed. Jacob Neusner v.dğr., Atlanta: Scholars Press, 1989, III, 111-25.

Lasker, Daniel J., “Judah Halevi”, Encyclopedia Judaica, 2. bs., XI, 492-500. 
Lasker, Daniel J., “Translations of Rabbi Judah Halevi's Kuzari” (seforim.blogspot.co.il /2017/06/translations-of-rabbi-judah-halevis.html; son erişim: 17.08.2018).

Lobel, Diana, Between Mysticism and Philosophy: Sufi Language of Religious Experience in Judah Ha-Levi's Kuzari, New York: State University of New York Press, 2000.

Malkiel, David J., “Three Perspectives on Judah Halevi’s Voyage to Palestine”, Mediterranean Historical Review, 25/1 (2010): 1-15.

Menocal, Maria Rosa, The Ornament of the World: How Muslims, Jews, and Christians Created a Culture of Tolerance in Medieval Spain, Boston - New York- London: Little, Brown and Company, 2002.

Meral, Yasin, "Petrus Alfonsi’nin 'Yahudilere Reddiye'sinde İslam Eleştirisi”, Dinî Araştırmalar, 16/43 (2013): 173-92.

Meral, Yasin, “Ortaçağ İslam Dünyasında Yahudi Düşüncesi”, Doğu’dan Batı’ya Düşüncenin Serüveni: Aklî Düşünce ve Felsefenin Doğu’dan Doğuşu, ed. Bayram Ali Çetinkaya - Ali Osman Kurt, İstanbul: İnsan Yayınları, 2015, I, 989-1018.

Mes'ûdî, Mürûcü'z-zeheb ve meâdinü’l-cevher, nşr. Muhammed Muhyiddîn Abdülhamîd, I-II, Beyrut: Dâru'l-fikr, t.y.

Moses Maimonides, The Guide for the Perplexed, çev. M. Friedländer, Skokie, Illinois: Varda Books, 2002.

Moses Maimonides, Code of Maimonides (Mishneh Torah), çev. Isaac Klein, ed. Leon Nemoy, I-XXI, New Haven: Yale University Press, 1972.

Moses Maimonides, “The Epistle to Yemen”, Epistles of Maimonides: Crisis and Leadership, çev. Abraham S. Halkin, Philadelphia: Jewish Publication Society, 1993.

Nemoy, Leon, “Contributions to the Textual Criticism of Judah ha-Levi’s Kitāb al-Khazarī”, The Jewish Quarterly Review, new series, 26/3 (1936): 221-26.

Oğuz, Emine Okumuş, Yehuda Halevi ve Kitabu'l-Huzarisi (yüksek lisans tezi), Sakarya Üniversitesi Sosyal Bilimler Enstitüsü, 2009.

Özervarlı, M. Sait, “Gazzâlî (Kelâm İlmindeki Yeri)”, DİA, 1996, XIII, 505-11.

Pines, S., "Shīite Terms and Conceptions in Judah Halevi's Kuzari", Jerusalem Studies in Arabic and Islam, 2 (1980): 165-251.

Pines, S., "Translator's Introduction: The Philosophic Sources of the Guide of the Perplexed", The Guide of the Perplexed, çev. Shlomo Pines, Chicago: The University of Chicago Press, 1963, I, s. LVII-CXXXIV.

Rosenzweig, Franz, Ninty-Two Poems and Hymns of Yehuda Halevi, ed. Richard A. Cohen, çev. Thomas Kovach v.dğr., New York: State University of New York Press, 2000.

Rubin, Uri, “Prophets and Progenitors in Early Shīa Tradition", Jerusalem Studies in Arabic and Islam, 1 (1979): 41-65.

Scheindlin, Raymond P., The Song of the Distant Dove: Judah Halevi's Pilgrimage, Oxford: Oxford University Press, 2007.

Scheindlin, Raymond P., "The Jews in Muslim Spain”, The Legacy of Muslim Spain, ed. Salma Khadra Jayyusi, Leiden: Brill, 1992, s. 188-200.

Schweid, Eliezer, The Classic Jewish Philosophers: From Saadia Through the Renaissance, çev. Leonard Levin, Leiden: Brill, 2008. 
Semev'el el-Mağribî, İfhâmü'l-Yehûd: Silencing the Jews, nşr. ve çev. Moshe Perlmann, New York: American Academy for Jewish Research, 1964; Türkçe'si: Yahudiliği Anlamak, çev. Osman Cilacı, İstanbul: İnsan Yayınları, 1995.

Shear, Adam, The Kuzari and the Shaping of Jewish Identity, 1167-1900, Cambridge: Cambridge University Press, 2008.

Shear, Adam, "Canonicity and the Authority of Works of 'Jewish Thought': Theoretical Perspectives and Some Examples from the Early Modern Reception of the Kuzari", Iggud: Selected Essays in Jewish Studies, vol. I: The Bible and Its World, Rabbinic Literature and Jewish Thought, ed. Baruch Schwartz v.dğr., Jerusalem: World Union of Jewish Studies, 2009, s. 115-28.

Silman, Yochanan, Philosopher and Prophet: Judah Halevi, the Kuzari and the Evolution of His Thought, çev. Lenn J. Schramm, New York: State University of New York Press, 1995.

Spero, Shubert, "Yehudah Halevi and Philosophical Use of Metaphor", Tradition, 45/3 (2012): 7-20.

Stampfer, Shaul, “Did the Khazars Convert to Judaism?”, Jewish Social Studies, 19/3 (2013): $1-72$.

Strauss, Leo, "The Law of Reason in the Kuzari", Proceedings of the American Academy for Jewish Research, 13 (1943): 47-96.

Taşağıl, Ahmet, “Hazarlar”, DİA, 1998, XVII, 116-20.

Toprak, M. Faruk, "Yehuda Halevi ve Şiirleri”, Eski Yeni, 1 (2006) 109-11.

Tudela’lı Benjamin - Ratisbon'lu Petachia, Ortaçağda İki Yahudi Seyyahın İslâm Dünyası Gözlemleri, çev. Nuh Arslantaş, İstanbul: MÜ İlâhiyat Fakültesi Vakfı Yayınları, 2009.

Wasserstrom, Steven M., Between Muslim and Jew: The Problem of Symbiosis under Early Islam, Princeton: Princeton University Press, 1995.

Wiener, Max, "Judah Halevi's Concept of Religion and a Modern Counterpart", Hebrew Union College Annual, Hebrew Union College Seventy-fifth Anniversary Publication 1875-1950, 23/1 (1950-51): 669-82.

Wolfson, Elliot R., "Merkavah Traditions in Philosophical Garb: Judah Halevi Reconsidered", Proceedings of the American Academy for Jewish Research, 57 (1990-91): 179-242.

Wolfson, Harry Austryn, "Hallevi and Maimonides on Prophecy", The Jewish Quarterly Review, new series, 32/4 (1942): 345-70; 33/1 (1942): 49-82.

Wolfson, Harry Austryn, "Maimonides and Halevi: A Study in Typical Jewish Attitudes Towards Greek Philosophy in the Middle Ages", The Jewish Quarterly Review, 2/3 (1912): 297-337.

Yahalom, Joseph, “Judah Halevi: Records of a Visitor from Spain”, The Cambridge Genizah Collections: Their Contents and Significance, ed. Stefan C. Reif, New York: Cambridge University Press, 2002, s. 123-33.

Zuckerman, Constantine, "On the Date of the Khazars' Conversion to Judaism and the Chronology of the Kings of the Rus Oleg and Igor: A Study of the Anonymous Khazar Letter from the Genizah of Cairo", Revue des Etudes Byzantines, 53 (1995): 237-70. 


\section{Judah Halevi's Defense of Judaism and Critique of Islam As Put Forth in His} Kuzari

Moses Maimonides, a famous medieval Jewish thinker, is perhaps the most recognized Jewish scholar in the western world as well as in Turkish academia. This is due primarily to his famous philosophical work entitled Dalālat al-ḥāirìn (known as Guide for the Perplexed to English speaking people), which is a classic of religious rationalism. Judah Halevi, on the other hand, is another important medieval Jewish thinker and poet, who, known as the most fervent defender of traditional Judaism and a fierce critic of religious rationalism, belongs to the opposite camp. Despite the fact that a huge body of scholarly work exists on Halevi in the West, including those that deal with the Arabic-Islamic background of his thought, he has not gained much recognition in Turkish academia. This paper aims to draw attention to Halevi's al-Kitāb al-Khazarī, widely known as Sefer ha-Kuzari, by analyzing its background and content. In this way, this paper presents an evaluation of the main points of Halevi's defense of the Jewish religion and critique of Islam as he put forth in his Kuzari.

Halevi, through his religious-nationalist poems as well as his polemical book, the Kuzari, had a significant impact on the Jews of his time and of later periods. In his Kuzari, which is written as a dialogue between a Khazar king (Khazari) and a Jewish scholar (haver), Halevi defends the Jewish religion and criticizes, directly or indirectly, the main beliefs and opinions of certain groups that he considers to be either external (philosophers, Muslims and Christians) or internal (Karaites) adversaries of Rabbinic Judaism. The Kuzari is also regarded as the first Jewish polemical book written against Islam. Even more important is the fact that since Halevi lived in a time and place that was dominated by Muslim Arab culture, he makes use of Islamic terminology to a great extent in the Kuzari. As demonstrated by a long chain of scholars including David Kaufmann, Ignaz Goldziher, Julius Guttman, David Baneth, Israel Efros, Harry Wolfson, Shlomo Pines, Diana Lobel and Ehud Krinis, Halevi borrows Arabic words and concepts not only from the Islamic (both Sunni and Shiite) literature of philosophy, kalām and tașawwuf, but also directly from the Qur'an and the hadith, integrating them into his own system of thought, i.e., into a Jewish context. The most important of these Islamic words or concepts are amr/amr Allāh, ittișāl, șafwa, qiyās, ijtihād, sanad, taqlìd, etc. It is also important to note that the main adversary groups that Halevi critiques in his Kuzari -namely, the philosophers (especially the Aristotelians), the kalām scholars and the Karaites- have one point in common: they all flourished in a Muslim culture and, in the case of the first two groups, consisted mostly of Muslim scholars. Accordingly, Greek philosophy, which was criticized by Halevi, had gained ascendency through the writings of Muslim philosophers and influenced Jewish scholars as well. As for Karaite Judaism, which emerged in Muslim Iraq, it was also influenced by the Muslim kalām tradition. Thus, for some scholars, the Kuzari should be seen as a clarion call made to persuade the Jewish elite of Spain, who came under the influence of Muslim culture with its emphasis on philosophy (i.e., Athens), to return to an authentic Jewish tradition (i.e., Jerusalem). This helps 
to explain the eventual decision of the haver, the main character of the Kuzari, as well as of Halevi himself to travel to the holy land to live and die there.

In light of this background knowledge, it is fair to consider Halevi's defense of Judaism in parallel to his critique of Islam. In dealing with different topics, Halevi often makes a comparison between the two religions and most of the time the main point of this comparison is the contrast made between particularism and universalism. According to Halevi, what is special about Judaism is that it is based upon the reality and experience of one people, i.e., the Jews, and therefore is particularistic and exclusivist in nature; Islam, on the contrary, has a universalistic and inclusivist orientation. From the Islamic point of view, the dependence of Jewish religion on ethnicity makes it a limited one, to say the least, whereas for Halevi this element of ethnicity or peoplehood, which is an inherent feature of Jewish religion, becomes the indicator of its authenticity. The reason for this is that Judaism, according to Halevi, is the only religion that depends on the religious experience of a whole people and not only of certain individuals. This element of peoplehood, namely the public experience of divine revelation (i.e., Sinai revelation) and its transmission by chosen individuals (i.e., prophets and sages) throughout the following generations, makes it a reliable and genuine revelation and tradition at one and the same time. Islam, on the other hand, is depicted by Halevi as a feeble and failed religion of universalism. However, this paper argues that this picture presented by Halevi does not go beyond a caricature of Islam, on the one hand, and a romantic and idealistic embellishment of Judaism, on the other.

Key words: Judah (Yehuda) Halevi, Sefer ha-Kuzari, al-Kitāb al-Khazarī, Judaism, Islam, Jews. 